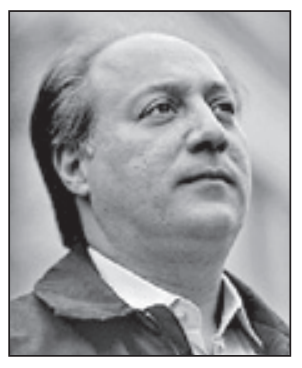

\title{
VÍCTOR ABRAMOVICH
}

Víctor E. Abramovich é advogado, professor adjunto regular da disciplina de Direitos Humanos na Faculdade de Direito da Universidade de Buenos Aires desde 2000 e atualmente coordena o Mestrado em Direitos Humanos e Políticas Públicas da Universidade Nacional de Lanús (UNLA). Em 1997 se integrou ao Centro de Estudos Legais e Sociais (CELS), ocupando a direção executiva da instituição de 2000 a dezembro de 2005. Em junho de 2005, foi eleito membro da Comissão Interamericana de Direitos Humanos (CIDH) da OEA pelo período de 2006 a 2009. Na CIDH, foi Relator para Colômbia, Guatemala, Cuba e Costa Rica. Foi Relator sobre Direitos das Mulheres (2006/2007) e Relator sobre Direitos dos Povos Indígenas. Foi nomeado representante da CIDH para o grupo de trabalho para monitoramento do Protocolo de San Salvador (2008). Como comissionado, participou ativamente da elaboração de diversos relatórios e estudos temáticos relacionados ao acesso à justiça. Entre outros, participou da elaboração do relatório temático da CIDH sobre "O acesso à justiça para as mulheres vítimas de violência nas Américas" (2006), e "Acesso à justiça e inclusão social. 0 caminho para o fortalecimento da democracia na Bolívia" (20007). Pelo mandato da CIDH, realizou o estudo sobre "Acesso à justiça como garantia dos direitos econômicos, sociais e culturais" (2008). Também elaborou o documento: "Diretrizes para elaboração de indicadores de progresso em direitos econômicos, sociais e culturais" (2008), que foi recentemente apresentado perante a Comissão de Assuntos Jurídicos e Políticos da OEA. Em 2009, como Relator temático, liderou o processo de elaboração do estudo: "O dever de proteção da propriedade comunal indígena sobre terras, territórios e recursos naturais" e do documento: "Diretrizes relativas ao dever estatal de consulta a respeito de projetos de desenvolvimento que possam afetar direitos dos povos indígenas".

Email:vabramovich@unla.edu.ar

\section{RESUMO}

O Sistema Interamericano de Direitos Humanos (SIDH) incidiu no processo de internacionalização dos sistemas jurídicos em vários países da América Latina na última década. A jurisprudência do SIDH começou a ser aplicada gradualmente nas decisóes de tribunais constitucionais e das cortes supremas nacionais e, nos últimos tempos, na formulação de algumas políticas estatais. Esse processo produziu importantes mudanças institucionais. Por outro lado, problemas e obstáculos têm provocado alguns retrocessos. O SIDH se encontra num período de fortes debates, que procuram definir suas prioridades temáticas e sua lógica de intervenção, num novo cenário político regional de democracias deficitárias e excludentes, que é diferente do cenário político que o viu nascer e dar seus primeiros passos. Este artigo procura apresentar um panorama geral de algumas discussóes estratégicas sobre o papel do SIDH no cenário político regional. Neste artigo sugere-se que o SIDH deveria no futuro aprofundar seu papel político, colocando foco nos padróes estruturais que afetam o exercício efetivo dos direitos pelos setores subordinados da população. Para tanto, deverá resguardar sua função subsidiaria aos sistemas de proteção nacionais e buscar que seus princípios e parâmetros se incorporem não apenas nas decisôes dos tribunais, mas também na orientação geral das leis e das políticas de governo.

Original em espanhol. Traduzido por Akemi Kamimura.

Recebido em setembro de 2009. Aprovado em dezembro de 2009.

\section{PALAVRAS-CHAVE}

Sistema Interamericano de Direitos Humanos - Violaçóes de direitos humanos Internacionalização dos sistemas jurídicos nacionais 


\section{DAS VIOLAÇÕES EM MASSA AOS PADRÕES ESTRUTURAIS: NOVOS ENFOQUES E CLÁSSICAS TENSÕES NO SISTEMA INTERAMERICANO DE DIREITOS HUMANOS}

Víctor Abramovich

\section{Introdução}

O Sistema Interamericano de Direitos Humanos (SIDH) incidiu no processo de internacionalização dos sistemas jurídicos em vários países da América Latina na última década. Nesse período, mais países aceitaram a competência da Corte Interamericana (como México e Brasil) e atribuíram à Convenção Americana a hierarquia constitucional ou superior às leis ordinárias em seus sistemas jurídicos. Os advogados, os juízes, os operadores do direito, os funcionários e os ativistas sociais aprenderam muito mais sobre a lógica de funcionamento do SIDH e começaram a utilizá-lo já não mais de maneira excepcional ou seletiva; também começaram a citar suas decisóes e argumentar com seus precedentes nos tribunais locais e em debates sobre políticas públicas. Com isso, a jurisprudência do SIDH começou a ser aplicada gradualmente nas decisóes dos tribunais constitucionais e das cortes supremas nacionais e, nos últimos tempos, ainda que de maneira incipiente, na formulação de algumas políticas estatais. Esse processo de incorporação do direito internacional dos direitos humanos no âmbito nacional produziu importantes mudanças institucionais.

Como exemplo, basta mencionar que os parâmetros jurídicos desenvolvidos pela jurisprudência da Comissão Interamericana (CIDH ou Comissão) e da Corte Interamericana (Corte IDH ou Corte) sobre anulação das leis de anistia de graves violaçôes de direitos humanos deram substrato legal para abertura de processos judiciais em face dos responsáveis de crimes contra a humanidade, no Peru e na Argentina. Os parâmetros fixados no caso Barrios Altos contra Peru foram 
decisivos para invalidar a lei de auto-anistia do regime de Fujimori e sustentar o julgamento dos crimes cometidos durante seu governo (PERU, Barrios Altos v. Peru, 2005), mas a decisáo do caso teve um efeito cascata e repercutiu na argumentaçáo jurídica dos tribunais argentinos ao invalidar as leis de obediência devida e ponto final (ARGENTINA, Simón, Julio Héctor e outros, 2005). A jurisprudência interamericana também está presente, ainda que de maneira mais tímida, em recentes decisóes dos tribunais superiores do Chile ${ }^{1}$. Além disso, mostra-se relevante nos debates sobre redução de penas no marco do processo de paz com os grupos paramilitares na Colômbia, assim como no tratamento político e judicial dos temas pendentes de justiça transicional na Guatemala, El Salvador, Honduras, Paraguai e Uruguai. Recentemente, foram apresentados perante a Corte IDH casos sobre crimes contra a humanidade cometidos no período da "guerra fria" no Brasil (CIDH, Julia Gomez Lund e outros v. Brasil, 2009c), na Bolívia (CIDH, Renato Ticona Estrada e outros v. República de Bolívia, 2007b) e no México (CIDH, Rosendo Radilla Pacheco v. México, 2008b) que repercutiram nas discussóes políticas e judiciais locais.

Esse processo, no entanto, não é linear. Enfrenta problemas e obstáculos além de ter sofrido alguns retrocessos. Ademais, o SIDH se encontra num período de fortes debates, que procuram definir suas prioridades temáticas e sua lógica de intervenção, num novo cenário político regional de democracias deficitárias e excludentes, que é diferente do cenário político que o viu nascer e dar seus primeiros passos, no marco dos processos ditatoriais da América do Sul nos anos setenta e dos conflitos armados da América Central dos anos oitenta.

Este artigo procura apresentar um panorama geral de algumas discussóes estratégicas que têm lugar tanto no interior dos órgáos interamericanos como da comunidade de direitos humanos sobre o papel do SIDH no cenário político regional.

Em primeiro lugar, procuraremos identificar o papel desempenhado pelos órgãos do SIDH em três momentos históricos distintos, enfocando em cada etapa as prioridades temáticas e as principais estratégias de intervenção. Assim, descreveremos o papel do SIDH na atualidade, seu caráter subsidiário em relação aos sistemas democráticos, seu uso estratégico pela sociedade civil local e internacional e pelos governos e outras instâncias estatais.

$\mathrm{Na}$ segunda parte do artigo, descreveremos a ampliação da agenda do SIDH em temas sociais e institucionais e apresentaremos os desenvolvimentos recentes sobre igualdade estrutural e reconhecimento de direitos diferenciados a favor de grupos subordinados. Nessa segunda parte, chamaremos atenção sobre o enfoque de certos conflitos de direitos humanos na regiáo, como evidência de padrốes sistemáticos de racismo, violência e exclusão e relacionaremos essa visão estrutural com a disposta no contexto dos casos individuais no marco de práticas de violaçóes em massa durante as ditaduras.

Por último, na terceira parte do artigo, apresentaremos brevemente uma agenda preliminar de discussão sobre alguns desafios do $\mathrm{SIDH}$, em especial a revisão de seus mecanismos de garantia, seus procedimentos de implementação de decisóes, suas regras processuais para o litígio em casos coletivos, assim como a relaçáo complexa de articulação e conflito com os sistemas de justiça nacionais. 


\section{Mudança de papéis em novos cenários políticos}

Não há dúvida de que o papel dos órgãos do sistema, tanto da Comissão como da Corte, modificou-se à luz das mudanças dos cenários políticos que ocorreram no continente americano.

Em seu início, o SIDH teve de enfrentar violaçóes sistemáticas e em massa cometidas sob sistemas de terrorismo de estado ou no marco de violentos conflitos armados internos. Seu papel foi, em síntese, o de um último recurso de justiça para as vítimas dessas violaçóes, que não podiam buscar auxilio nos sistemas de justiça internos devastados ou manipulados. Nesses tempos iniciais de asfixia política no interior dos Estados nacionais, os Relatórios sobre países da Comissão serviram para documentar situaçóes com rigor técnico e para legitimar as denúncias das vítimas e suas organizaçôes, além de expor e desgastar a imagem dos ditadores nas esferas local e internacional.

Posteriormente, durante as transiçóes pós-ditatoriais da década de 80 e início da década de 90, o SIDH já apresentava um sentido mais amplo, à medida que procurou acompanhar os processos políticos dirigidos ao tratamento do passado autoritário e suas seqüelas nas instituições democráticas. Nesse período, o SIDH começou a delinear os princípios fundamentais sobre o direito à justiça, à verdade e à reparação de graves violaçóes, em massa e sistemáticas, de direitos humanos. Fixou os limites das leis de anistia. Estabeleceu as bases para a proteção estrita da liberdade de expressão e a proibição de censura prévia. Invalidou os tribunais militares para julgar civis e casos de direitos humanos, limitando um espaço de ação das forças militares, que ainda eram atores de oposição nas transições e buscavam impunidade pelos crimes do passado. Protegeu o habeas corpus, as garantias processuais, a ordem constitucional democrática e a divisão dos poderes estatais ante a possibilidade, ainda latente na época, de retrocessos autoritários e de abusos dos estados de exceção (CORTE IDH, 1986, 1987a, 1987b) ${ }^{2}$. Interpretou o alcance das limitaçóes impostas pela Convenção na aplicação da pena de morte, invalidando a pena de morte a menores de idade e doentes mentais, a aplicaçáo de pena de morte como única sanção diante de um crime e fixando parâmetros estritos de devido processo, como garantia para limitar a arbitrariedade dos tribunais na aplicação da pena capital. Ademais, abordou temas sociais que expressavam atrasos discriminatórios na região ao afirmar, por exemplo, a igualdade das mulheres perante a lei em seus direitos familiares e matrimoniais e os direitos sucessórios de filhos nascidos fora do casamento, que os códigos civis americanos consideravam ainda como "ilegítimos".

Durante a década de 90, além disso, enfrentou com firmeza regimes de terrorismo de estado, como o regime peruano de Alberto Fujimori, documentando e denunciando como haviam sido realizadas, na América do Sul, nos anos 70, práticas sistemáticas de desaparecimento e torturas, e a impunidade que acompanhava esses crimes de Estado. Também foi um ator relevante no acompanhamento das graves violaçóes de direitos humanos e de direito internacional humanitário cometidas no marco do conflito armado interno na Colômbia.

O atual cenário regional é sem dúvida mais complexo. Muitos países da região passaram por experiências transicionais, mas não alcançaram uma consolidação de 
seus sistemas democráticos. Trata-se de um cenário de democracias representativas, que deram alguns passos importantes, por exemplo, na melhoria dos sistemas eleitorais, no respeito à liberdade de imprensa, no abandono das práticas de violência política; mas que apresentam sérias fragilidades institucionais, tais como sistemas de justiça náo efetivos e sistemas policiais e penitenciários violentos. Além disso, essas democracias convivem com níveis alarmantes de desigualdade e exclusão, que provocam, por sua vez, um clima de constante instabilidade política.

Nesse novo cenário, os órgãos do SIDH procuram não apenas reparar as vítimas nos casos particulares, mas também fixar um conjunto de princípios e parâmetros, com o propósito de incidir na qualidade dos processos democráticos e no fortalecimento dos principais mecanismos domésticos de proteção dos direitos. O desafio do SIDH nessa etapa é melhorar as condiçóes estruturais que garantem a efetividade dos direitos em nível nacional. Esse enfoque tem como pressuposto o caráter subsidiário dos mecanismos de proteção internacional em relação às garantias desses direitos nos próprios Estados. De tal modo que reconhece os claros limites da supervisão internacional e ao mesmo tempo resguarda a necessária margem de autonomia dos processos políticos nacionais com o objetivo de alcançar melhores níveis de realização e vigência dos direitos humanos.

Desse modo, a manutenção da autonomia dos Estados se expressa no alcance da interpretação feita pelo SIDH de algumas regras processuais que definem seu grau de intervenção. Entre estas regras está a regra que exige o "prévio esgotamento" dos recursos disponíveis em âmbito internos do país para remediar a situação e a regra da "quarta instância", em virtude da qual o SIDH se abstém de revisar a correção ou equívoco das decisóes dos tribunais nacionais em matérias não disciplinadas diretamente pela Convenção, caso sejam respeitadas as garantias do procedimento.

A primeira regra, do "prévio esgotamento de recursos internos", embora tenha natureza processual, funciona como um elemento chave para compreender a dinâmica de funcionamento de todo o sistema interamericano e em especial sua função subsidiária. Ao obrigar a apresentar e esgotar o sistema de ações e recursos disponíveis no sistema judicial do Estado nacional, oferece-se a cada Estado a possibilidade de solucionar o conflito e reparar as violaçóes antes que o assunto seja examinado na esfera internacional. $\mathrm{O}$ alcance dessa regra na jurisprudência dos órgãos do SIDH define o grau de intervençáo que o mecanismo internacional está disposto a exercer nas diferentes situações, com base na idoneidade e eficácia do sistema de justiça nacional.

A segunda regra, denominada "quarta instância", funciona como uma espécie de margem de deferência aos sistemas judiciais nacionais, pois reconhece sua ampla margem de autonomia para atuar na interpretação das normas locais e na decisão dos casos concretos, sob a única condição de que sejam respeitadas as garantias processuais estabelecidas na Convenção ${ }^{3}$.

O SIDH também tem percebido um novo cenário de democracias constitucionais na região, reconhecendo margens de deferência aos Estados nacionais na definição de determinados temas delicados, como o modelo dos sistemas eleitorais em função de cada contexto social e histórico, sempre que se respeite o exercício igualitários dos direitos políticos ${ }^{4}$.

Em alguns casos, ademais, a $\mathrm{CIDH}$ tem considerado, especialmente em sua 
análise da aplicação da Convenção em casos concretos, os argumentos desenvolvidos pelos tribunais superiores dos Estados que aplicaram a mesma Convenção ou que analisaram os mesmos temas com seus próprios parâmetros constitucionais. Não se trata do reconhecimento de margens de deferência em sentido estrito, mas de especial consideração a certas decisóes de tribunais internos como ponto de apoio ou como base de argumentação, que é tida particularmente em conta pela CIDH ao realizar seu próprio exame do caso. Esse tipo de argumentação sustentada em decisóes de tribunais locais foi considerado na análise sobre a razoabilidade de leis internas que impuseram restriçóes a direitos fundamentais. Foi o que fez, por exemplo, considerando razoáveis os argumentos de tribunais locais que determinaram a proporcionalidade de condenaçóes de danos e prejuízos por difamação, a fim de decidir se houve violação à liberdade de imprensa (CIDH, Dudley Stokes v. Jamaica, 2008a). Também ao examinar uma decisão de um tribunal nacional acerca da razoabilidade de uma reforma do sistema de previdência social, a fim de determinar se essa reforma cumpria com parâmetros de proporcionalidade e progressividade e, portanto, se existiam restriçôes legítimas aos direitos sociais (CIDH, Associação Nacional de Ex-Servidores do Instituto Peruano de Previdência Social e outras v. Peru, 2009d).

Entretanto, no novo cenário político regional, além de uma mudança de enfoque, é possível identificar também uma variação na agenda.

$\mathrm{Na}$ etapa das transiçóes, como dissemos, o SIDH contribuiu para alguns debates institucionais, como a subordinação das forças armadas ao controle civil e sua intervenção em assuntos de segurança interna e ao alcance dos privilégios e competências da justiça penal militar. Tais temas tinham vinculação direta com o tratamento das violaçóes do passado pois implicavam em definir o poder de veto ou de pressão dos militares nas transiçóes. Na etapa posterior às transiçóes, a agenda institucional se amplia consideravelmente pelo tipo de assunto que chega ao conhecimento do SIDH.

Um lugar central na nova agenda do SIDH é ocupado pelos temas relativos ao funcionamento dos sistemas de administração da justiça, que têm impacto ou relação com o exercício dos direitos humanos. Não apenas as garantias processuais dos acusados em processos criminais, mas também o direito de algumas vítimas que não alcançam um acesso igualitário à justiça e sofrem padróes estruturais de impunidade frente a determinados crimes estatais, como a violência das instituiçóes policiais ou penitenciárias. As estratégias de luta contra o crime organizado e o terrorismo internacional retomaram algumas discussóes da agenda transicional relativas à administração da justiça, como o debate sobre a competência do foro militar. Nesse sentido, cobrou centralidade o monitoramento das políticas de segurança cidadá. Também as garantias de independência e imparcialidade dos tribunais e diferentes questóes relacionadas à ampla proteção convencional do devido processo e do direito à proteção judicial, inclusive em relação à tutela judicial dos direitos sociais.

Outra categoria de problemas institucionais examinados pelo SIDH na etapa pós-transições refere-se aos temas vinculados à preservação da esfera pública democrática nos países da regiáo. Nesta categoria incluem-se desde temas relacionados com liberdade de expressão, liberdade de imprensa, acesso à informação pública, direito de reunião e associação, liberdade de manifestação e, de maneira incipiente, 
alguns temas relativos à igualdade e devido processo judicial em matéria eleitoral.

No que diz respeito a outros temas, um aspecto prioritário da agenda do SIDH nessa etapa refere-se a novas demandas de igualdade de grupos e coletividades que se projetam sobre muitos dos assuntos institucionais que antes mencionamos, pois abrangem situações de setores excluídos que vêem afetados seus direitos de participação e expressão, sofrem padrôes de violência institucional ou social, ou obstáculos ao acesso à esfera pública, ao sistema político, ou à proteção social ou judicial. Voltaremos especificamente a essa questão nos pontos 4 e 5 .

Além da ampliação da agenda, também se observa nessa terceira etapa uma mudança na forma de intervenção do SIDH e no impacto que tem suas decisôes na esfera local.

A jurisprudência do SIDH teve um considerável impacto na jurisprudência dos tribunais nacionais que aplicam as normas de direito internacional dos direitos humanos. É importante considerar que as decisões adotadas pelos órgãos do sistema num caso concreto tem um valor heurístico de interpretação dos tratados aplicáveis ao conflito que transcende às vítimas afetadas no processo. Além disso, essa jurisprudência internacional costuma ser utilizada como guia para as decisóes posteriormente adotadas em nível doméstico pelos tribunais nacionais, que procuram assim evitar que os Estados possam ser expostos a petiçóes e eventuais condenaçóes ante as instâncias internacionais. Esse processo de globalização de parâmetros de direitos humanos, embora não tenha alcançado igual grau de desenvolvimento em toda a região e esteja sujeito à precariedade dos sistemas de justiça, teve um incontestável impacto positivo na transformação desses mesmos sistemas judiciais e gerou uma maior atenção das autoridades estatais ao desenvolvimento do SIDH. Assim, a jurisprudência fixada pela Comissão e especialmente pela Corte incidiu em diversas alteraçóes jurisprudenciais nos países da região, em temas relacionados com a frágil e deficitária institucionalidade das democracias latino-americanas. Podemos mencionar, por exemplo, a jurisprudência sobre a descriminalização do desacato e das críticas divulgadas pela imprensa, o acesso à informação pública, os limites da persecução penal de manifestaçôes públicas pacíficas. A fixação de limites e condiçóes objetivas para a concessão de prisão preventiva, das possibilidades de detenção das polícias e para o uso da força pública. A determinação de padrôes para um sistema penal diferenciado para os menores de idade; sobre o direito de apelar perante um tribunal superior sobre condenações penais, a participação das vítimas de crimes de estado nos processos judiciais. Também o reconhecimento de condiçóes mínimas de devido processo na esfera administrativa e a revisão judicial de atos administrativos, assim como de garantias básicas nos processos de remoção de magistrados, entre outros assuntos de grande relevância para o funcionamento das instituiçóes e ordem constitucional nos Estados (MENDEZ; MARIEZCURRENA, 2000, ABRAMOVICH; BOVINO; COURTIS, 2007).

Porém, a incidência do SIDH não se limita ao impacto de sua jurisprudência sobre a jurisprudência dos tribunais locais. Outra via importante para o fortalecimento da institucionalidade democrática nos Estados surge da capacidade do SIDH de influenciar na orientação geral de algumas políticas públicas e nos processos de formulação, implementação, avaliação e fiscalização das mesmas. Assim, é comum 
observar que as decisóes individuais adotadas num caso específico costumam impor aos Estados obrigaçóes de formular políticas para reparar a situação que originou a petição e estabelecem, inclusive, o dever de abordar os problemas estruturais que estão na raiz do conflito analisado no caso em questão.

A imposição dessas obrigações positivas em geral é precedida da análise dos parâmetros jurídicos, das políticas implementadas, ou da falta de ação (omissão) do Estado. Essas obrigações podem consistir em alterações de políticas existentes, reformas legais, a implementação de processos participativos para formulação de novas políticas públicas e, muitas vezes, na reversão de certos padróes de comportamento que caracterizam o acionar de certas instituiçóes do Estado que promovem violaçóes como, por exemplo, violência policial, abuso e tortura nas prisóes, aquiescência do estado frente a situaçóes de violência doméstica, políticas de deslocamentos forçados de população no marco de conflitos armados, desalojamentos em massa de povos indígenas de suas terras ancestrais.

Ademais, no âmbito dos casos individuais, o SIDH, especialmente a Comissão, promove processos de soluçáo amistosa ou negociações entre os peticionários e os Estados, nos quais os Estados muitas vezes se comprometem a implementar reformas institucionais ou criar mecanismos de consulta para a definição de políticas com a sociedade civil. Assim, no marco de diversos processos de soluçôes amistosas, conseguiu-se, por exemplo, que alguns Estados modifiquem suas leis e, por exemplo, derroguem a figura do desacato que permitia a criminalização da crítica política; criem procedimentos para averiguar a verdade sobre o paradeiro de pessoas desaparecidas; implementem programas em massa de reparação às vítimas de violações de direitos humanos ou programas de reparação coletiva de comunidades afetadas pela violência; implementem programas oficiais de proteção de vítimas, testemunhas e defensores de direitos humanos; revisem processos penais em que foram determinadas condenações sem o devido processo, ou revejam o arquivamento de causas penais em que agentes do estado acusados de violar direitos humanos foram absolvidos de maneira fraudulenta; adéqüem normas do código civil que discriminavam filhos nascidos fora do casamento, ou normas do código civil que discriminavam as mulheres em relação aos seus direitos no casamento; ou implementem leis do cotas para mulheres nos processos eleitorais, ou leis sobre violência contra as mulheres, ou implementem protocolos para a realização de abortos legais, ou derroguem leis migratórias que afetavam os direitos civis dos imigrantes.

A CIDH realiza também recomendações sobre políticas públicas em seus relatórios gerais por países. Neles, a CIDH analisa situaçóes concretas de violaçóes e tece recomendações que orientam políticas estatais com base em parâmetros jurídicos ${ }^{5}$.

A Comissão também pode emitir relatórios temáticos que abrangem temas de interesse regional ou que concernem a vários estados. Esse tipo de relatório tem enorme potencial para fixar standards e princípios e revelar situações coletivas ou problemas estruturais que podem não estar devidamente refletidos na agenda dos casos individuais. Além disso, tem uma perspectiva promocional mais definida que nos relatórios por país, que costumam ser vistos como mecanismos de exposição dos Estados perante a comunidade internacional e seus públicos locais. O processo de elaboração dos relatórios temáticos, por sua vez, permite à Comissão dialogar com 
atores sociais locais e internacionais relevantes para essa temática, obter opiniáo de peritos, de agências de cooperação e instituiçóes financeiras internacionais, de órgãos políticos e técnicos da OEA, e iniciar vínculos com os funcionários encarregados de promover as políticas nos campos analisados ${ }^{6}$.

Por último, a Corte Interamericana de Direitos Humanos (Corte IDH) pode emitir opinióes consultivas, que servem para examinar problemas concretos além dos casos contenciosos, e fixar o alcance das obrigaçóes estatais que emanam da Convenção e de outros tratados de direitos humanos aplicáveis no âmbito regional, tais como a situação jurídica dos trabalhadores migrantes e os direitos humanos das crianças e adolescentes. Nessas opinióes consultivas, em algumas ocasióes a Corte tentou fixar marcos jurídicos para o desenvolvimento de políticas. Assim, por exemplo, na Opiniáo Consultiva n. 18 procura definir uma série de princípios que devem orientar as políticas migratórias dos Estados, e em especial o reconhecimento de certos direitos sociais básicos aos imigrantes em situação irregular. $\mathrm{Na}$ Opinião Consultiva 17 procura orientar as políticas dirigidas à infância impondo limites às políticas criminais dirigidas às crianças.

\section{O SIDH como cenário de ativismo transnacional e da açáo política dos governos}

Ao mesmo tempo, o SIDH, tanto a Comissão como a Corte, transformaramse gradualmente num palco privilegiado de ativismo da sociedade civil, que desenvolveu estratégias inovadoras para aproveitar no âmbito nacional a repercussão internacional dos casos e situações denunciadas nas denominadas estratégias de bumerangue (NELSON; DORSEY, 2006, RISSE; SIKKINK, 1999, SIKKINK, 2003).

As organizaçóes sociais se valeram desse palco internacional não só para denunciar violaçôes e tornar visíveis certas práticas estatais questionadas, mas também para alcançar posiçôes privilegiadas de diálogo com seus governos ou com aliados no interior desses e para reverter as relaçôes de força e alterar a dinâmica de alguns processos políticos. Em algumas ocasióes, isso tem facilitado a abertura de espaços de participação e incidência social na formulação e implementação de políticas e no desenvolvimento de reformas institucionais. Também foram essas organizaçóes sociais que incorporaram com maior freqüência os standards jurídicos fixados pelo SIDH como parâmetro para avaliar e fiscalizar açóes e políticas dos Estados e, em algumas ocasióes, para impugná-las perante os tribunais nacionais ou ante a opiniáo pública local e internacional.

Nos países da América Latina, muitas organizaçóes de direitos humanos e outras organizaçóes sociais que atuam com uma perspectiva de direitos - como organizações feministas, de controle cidadão, ambientais e defensoras de usuários e consumidores entre outras - além de fiscalizar as açóes estatais, incorporaram novas estratégias de diálogo e negociação com os governos, a fim de incidir na orientação de suas políticas e conseguir transformações no funcionamento das instituiçôes públicas. A mudança de perspectiva propóe incorporar ao trabalho tradicional de denúncia de violações uma ação preventiva e de promoção capaz de evitá-las. 
Dessa forma, a comunidade de usuários do SIDH cresceu consideravelmente em número e se tornou mais variada, plural e complexa. O SIDH começou a ser utilizado de maneira muito mais freqüente pelas organizaçóes sociais locais, e já não mais apenas pelas tradicionais organizaçóes internacionais que contribuíram para dar-lhe forma nos tempos iniciais, ou por aquelas organizaçóes que se especializaram nos seus mecanismos. Alguns dos casos mais bem-sucedidos em termos de mudanças sociais foram promovidos e sustentados por coligações ou alianças em "escala múltipla", isto é, com capacidade de atuar em diferentes esferas locais e internacionais. Em geral, trata-se de coligaçóes formadas por organizaçôes internacionais ou regionais com experiência na utilização do SIDH e organizaçôes locais com capacidade de mobilização social, diálogo e incidência nos governos e na opiniáo pública. Esse tipo de parceria permitiu melhorar a articulação das estratégias aplicadas no cenário internacional com as empregadas no âmbito local.

Ao mesmo tempo, muitas organizaçôes locais gradualmente adquiriram experiência suficiente para atuar de maneira independente no SIDH e, em algumas ocasióes, impulsionaram alianças entre seus pares de outros países da região para impulsionar no SIDH temas regionais de interesse comum, como a violência policial ou o acesso à informação pública ou a violência contra as mulheres (MACDOWELL SANTOS, 2007). Assim, por exemplo, uma rede de organizaçóes especializadas em questóes de violência policial e sistema penal foi a causa para que a Comissão se envolvesse na preparação de um relatório temático sobre segurança cidadã e direitos humanos, fixando parâmetros definidos para orientar políticas democráticas de segurança em toda a região. Também foi resultado da intervenção de redes de organizaçóes sociais o recente relatório sobre a situação dos defensores de direitos humanos elaborado pela Comissão e o processo de monitoramento de suas recomendaçóes nos Estados. Uma rede de organizações não governamentais e meios comunitários de imprensa promoveram a adoção pela CIDH de uma série de princípios básicos para regulação da radiodifusão.

Além das organizaçóes com perfil jurídico, que costumam representar as vítimas ou grupos de vítimas, determinadas ações perante o SIDH envolvem com freqüência organizaçóes de base ou comunitárias, que integram também redes ou alianças com aquelas, para impulsionar casos, audiências temáticas ou promover relatórios da CIDH. O trabalho das Relatorias da CIDH sobre direitos dos povos indígenas e sobre discriminação racial ampliaram consideravelmente a utilização do SIDH por líderes de povos indígenas e de comunidades afro-americanas. Também aumentou a participação de sindicatos na parceria com organizaçóes de direitos humanos, enfocando temas relativos à liberdade sindical e justiça trabalhista e previdenciária.

Nos países onde o SIDH é mais conhecido, como Argentina e Peru, por exemplo, advogados particulares incorporaram esse plano internacional como uma nova instância no litígio de diversos temas, como assuntos previdenciários relativos à demora dos processos e aplicação de leis de emergência ou garantias dos acusados em processos penais.

Mas o SIDH também foi utilizado de forma ativa por alguns Estados ou por organismos públicos com competência em direitos humanos para esclarecer certas questóes e impulsionar agendas nacionais ou regionais. Esses processos foram 
favorecidos com uma paulatina configuração de burocracia estatal especializada na administração desses temas, que costuma repercutir em alguns aspectos da gestão pública, tais como secretarias e comissóes de direitos humanos, setores especializados nas chancelarias, defensorias públicas, procuradorias de direitos humanos, ministérios públicos e promotorias especializadas, entre outros. Em algumas ocasióes, quando os governos têm políticas definidas nessa matéria, um caso no SIDH costuma ser considerado, pelas áreas interessadas do mesmo governo, uma oportunidade de repercussão política para superar resistências internas no próprio Estado ou em outros setores sociais. Isso pode ser observado com clareza em alguns processos de solução amistosa que incentivaram mudanças na legislação e em políticas nacionais (TISCORNIA, 2008). Eventualmente, os peticionários são também órgãos públicos independentes que litigam e em algumas circunstâncias negociam com a representação do governo. $\mathrm{O}$ exemplo freqüente são os ministérios públicos no âmbito penal que se transformaram em importantes usuários do SIDH.

Alguns Estados utilizaram, por exemplo, as opinióes consultivas da Corte para incitar temas de direitos humanos que ocupam um espaço central em sua política externa como a proteção de seus nacionais que emigram a outros países centrais. Foi precisamente o México que promoveu os pronunciamentos do sistema sobre assistência consular em processos com pena de morte e sobre direitos trabalhistas de imigrantes em situação irregular, conseguindo que os Estados Unidos se apresentassem perante a Corte como Amicus Curiae para defender os postulados de suas próprias políticas. Recentemente o governo argentino, de maneira articulada com algumas organizaçóes sociais, promoveu uma discussão sobre a legalidade da prática de nomeação de juízes ad hoc pelos Estados nos litígios perante a Corte e a potencial ameaça ao princípio da imparcialidade. Além disso, nos últimos três anos foram apresentadas duas demandas interestatais, pela primeira vez desde a entrada em vigor da Convenção Americana ${ }^{7}$.

Também aumentou o número de funcionários públicos, juízes, defensores, promotores, operadores judiciais, que compareceram à $\mathrm{CIDH}$ e à Corte IDH buscando proteção cautelar urgente diante de ameaças, intimidaçóes ou atos de violência como represália pelo cumprimento de suas funçôes. Essas situaçôes rompem o esquema clássico do SIDH protegendo vítimas frente aos abusos dos Estados autoritários e monolíticos e colocam em evidência que o cenário de ação do SIDH é ainda mais complexo na atualidade, em relação a Estados democráticos que manifestam em seu interior ambigüidades, disputas e contradiçóes.

\section{Uma agenda ampliada. Exclusão e degradaçáo institucional}

Essa mudança gradual do papel do SIDH no novo cenário político foi acompanhado também por uma mudança gradual da agenda de temas tratados pelo SIDH. Embora, como vimos, alguns dos velhos temas não tenham sido superados nem substituídos, como os conflitos da justiça transicional. A nova agenda se compóe pela incorporação de novos temas que convivem com os assuntos tradicionais.

Nos últimos anos foi se consolidando no SIDH uma agenda vinculada aos problemas derivados da desigualdade e exclusão social. Isso a partir da constatação de 
que depois de processos complicados de transição, as democracias latino-americanas se encontram seriamente ameaçadas pelo aumento contínuo de disparidades sociais e exclusão de amplos setores da população dos sistemas políticos e dos benefícios do desenvolvimento, o que impóe limites estruturais ao exercício dos direitos sociais, políticos, culturais e civis.

Os problemas de desigualdade e exclusão se refletem na degradação de algumas práticas institucionais e no funcionamento deficiente dos Estados democráticos, o que produz novas formas de violação dos direitos humanos, muitas vezes relacionadas com as práticas dos Estados autoritários de décadas passadas. Náo se trata de Estados que se organizam para violar sistematicamente direitos, nem que planejam em suas esferas superiores açôes deliberadas para violá-los em massa, mas de Estados com autoridades eleitas legitimamente, que não são capazes de reverter e impedir práticas arbitrárias de seus próprios agentes, nem de assegurar mecanismos efetivos de responsabilidade por seus atos, como conseqüência do precário funcionamento de seus sistemas judiciais (PINHEIRO, 2002). Os setores sociais sob condiçôes estruturais de desigualdade e exclusão são as principais vítimas desse déficit institucional, o que se reflete em alguns conflitos que ocupam a atenção do SIDH: a violência policial marcada pelo recorte social ou racial, a superpopulação e a tortura nos sistemas penitenciários, cujas vítimas habituais são os jovens de classes populares; as práticas generalizadas de violência doméstica contra as mulheres, toleradas pelas autoridades estatais; a privação da terra e da participação política dos povos e comunidades indígenas; a discriminação da população afrodescendente no acesso à educação e à justiça; o abuso das burocracias contra os imigrantes indocumentados; os deslocamentos em massa de população rural em contextos de violência social ou política.

Daí que uma das principais contribuiçóes e ao mesmo tempo um dos principais desafios do SIDH, em relação aos problemas regionais originados na exclusão e degradação institucional, reside na capacidade de guiar com parâmetros e princípios a atuação dos Estados democráticos nas situações concretas, tanto a jurisprudência dos tribunais, a fim de determinar o alcance dos direitos, como os processos de formulação de políticas públicas, contribuindo desse modo para o fortalecimento das garantias institucionais e sociais desses direitos nos diversos espaços nacionais.

Frente a esse tipo de situação, a CIDH e a Corte IDH procuram examinar náo apenas os casos ou conflitos isolados, mas também os contextos sociais e institucionais em que esses casos e conflitos se desenvolveram e adquiriram sentido. Assim como na época das ditaduras e terrorismo de estado, o SIDH havia observado a situação de determinadas vítimas, a execução e o desaparecimento de determinadas pessoas, em função do contexto de violaçôes em massa e sistemáticas de direitos humanos; na atualidade, em diversas situaçóes, procura ampliar o foco para situar os fatos específicos em padróes estruturais de discriminação e violência contra grupos ou setores sociais determinados. Para tanto, o SIDH se baseia numa concepção do princípio da igualdade, que buscaremos apresentar brevemente em seguida. A reinterpretação do princípio da igualdade permite ao SIDH abordar temáticas sociais a partir de uma reinterpretação do alcance dos direitos civis e políticos estabelecidos na Convenção Americana. 


\section{Os direitos num cenário de desigualdade estrutural}

Consideramos importante, para ilustrar a mudança de enfoque mencionada, analisar algumas intervençôes do SIDH em assuntos referidos a questôes de igualdade relacionados com diversas formas de violência ou com assuntos relativos à participação política e acesso à justiça. Esses precedentes marcam uma linha jurisprudencial que tende a uma leitura em chave social de diversos direitos civis da Convenção Americana e afirmam a existência de deveres de ação positiva e não somente de obrigaçóes negativas dos Estados. Esses deveres positivos costumam ser impostos com maior intensidade como resultado do reconhecimento de que determinados setores sociais vivem em condiçóes estruturais de desvantagem no acesso ou exercício de seus direitos básicos.

Se observarmos a evolução da jurisprudência sobre igualdade no sistema interamericano, concluiremos que o SIDH demanda dos Estados um papel mais ativo e menos neutro, como garantidor não apenas do reconhecimento dos direitos, mas também da possibilidade efetiva de exercê-los. Nesse sentido, a perspectiva histórica sobre a jurisprudência do SIDH marca uma evolução de um conceito de igualdade formal, elaborado na fase da transição, para um conceito de igualdade material que começa a se consolidar na etapa atual de fim das transiçóes para a democracia, quando a temática da discriminação estrutural se apresenta com mais forca no tipo de casos e assuntos considerados pelo SIDH. Assim se avança de uma idéia de igualdade como não discriminação a uma idéia de igualdade como proteçáo de grupos subordinados. Isso significa que se evolui de uma noção clássica de igualdade, que indica a eliminação de privilégios ou diferenças injustas ou arbitrárias, que busca gerar regras iguais para todos e demanda do Estado uma forma de neutralidade ou "cegueira" frente à diferença. Desloca-se para uma noção de igualdade substantiva, que demanda do Estado um papel ativo para produzir equilíbrios sociais, a proteção especial de determinados grupos que sofrem processos históricos ou estruturais de discriminação. Essa última noção pressupõe um Estado que abandone sua neutralidade e que conte com ferramentas de diagnóstico da situação social para saber quais grupos ou setores devem receber num momento histórico determinado medidas urgentes e especiais de proteção.

Num relatório recente da $\mathrm{CIDH}$ são sistematizadas algumas decisões jurisprudenciais do sistema que marcam essa evolução do conceito de igualdade em relação aos direitos das mulheres (CIDH, 2007a).

Há algumas conseqüências muito claras a partir da adoção de uma idéia de igualdade estrutural no sistema interamericano. A primeira é que as açôes de natureza afirmativa que adota o Estado não podem ser, a princípio, invalidadas sob uma noção de igualdade formal. Em todo caso, a impugnação de açôes afirmativas deverá se basear em críticas concretas de sua razoabilidade em função da situação dos grupos beneficiários num momento histórico determinado. A segunda conseqüência é que os Estados não só têm o dever de não discriminar, mas que, diante de certas situações de desigualdade de caráter estrutural, têm a obrigação de adotar ações afirmativas ou positivas de compensação para assegurar o exercício dos direitos por determinados grupos subordinados. Uma terceira conseqüência é que práticas 
ou políticas que são aparentemente neutras, mas que podem ter um impacto ou um efeito discriminatório sobre certos grupos em desvantagem, também podem violar o princípio da igualdade. Isso já foi destacado pela Corte, no caso das meninas Yean e Bosico contra República Dominicana (CORTE IDH, 2005d). Uma série de práticas que aparentemente podem ser neutras ou podem não expressar uma vontade deliberada de discriminar um setor podem ter como efeito a discriminação de um grupo definido e, por isso, podem ser considerados violadores da regra da igualdade. Essas conseqüências partem de uma leitura na chave social do princípio da igualdade, já que implicam reconhecer como determinadas açóes do Estado podem gerar impacto não numa pessoa individual, mas num grupo ou num setor subordinado da populaçáo. Isso equivale a mudar de lente e ampliar a prisma para observar o contexto social e as trajetórias sociais de certas pessoas como parte de um grupo ou coletivo subjugado ou discriminado. Daí que não só serão violadores do princípio da igualdade aquelas normas, práticas ou políticas que deliberadamente excluam determinado grupo, sem um argumento razoável ou lógico, mas também as que podem ter efeitos ou impactos discriminatórios ${ }^{8}$.

Ao mesmo tempo, esse conceito de igualdade se reflete na forma em que o SIDH começou a reler as obrigaçóes dos Estados em matéria de direitos civis e políticos em certos contextos sociais.

Podemos indicar alguns antecedentes importantes sobre a extensão dos deveres de proteção do Estado frente à atuação de atores não estatais, por exemplo, em matéria de violência contra as mulheres. A CIDH fixou deveres especiais de proteção estatal vinculados ao direito à vida e à integridade física em função de uma interpretação do princípio da igualdade na mesma linha com que a expomos anteriormente. No caso de Maria da Penha Fernandes contra Brasil, a CIDH, diante de um padrão estrutural de violência doméstica que afetava as mulheres da cidade de Fortaleza no Estado de Ceará, acompanhado por uma prática general de impunidade judicial frente a esse tipo de casos criminais e a negligência do governo local em implementar medidas efetivas de prevenção, estabeleceu que o Estado federal havia violado o direito à integridade física da vítima e o direito à igualdade perante a lei. Também estabeleceu que os Estados têm um dever de ação preventiva diligente para evitar práticas de violência contra as mulheres, ainda que diante da atuação de atores não estatais, com base não apenas no artigo $7 \mathrm{da}$ Convenção de Belém do Pará, mas também na própria Convenção Americana. A responsabilidade do Estado se originava de não ter adotado medidas preventivas com a devida diligência para evitar que essa forma ampliada de violência existisse e se reproduzisse em prejuízo de determinado grupo ou coletividade. A CIDH avalia fundamentalmente a existência de um padrão ou "modelo de conduta sistemática" na resposta do Estado, que expressa a seu juízo uma forma de tolerância pública com a situação de violência denunciada não apenas em prejuízo da vítima, mas em relação a outros casos idênticos ou com características comuns. $\mathrm{O}$ enfoque, como dissemos, vai mais além da situação particular da vítima individual, pois se projeta para a avaliação da situação de discriminação e subordinação de um grupo social determinado. A situação estrutural do grupo de mulheres afetadas pela violência, por um lado, qualifica os deveres de prevenção do Estado e suas obrigaçóes de 
reparação no caso particular, mas além disso justifica o tipo de recomendaçóes de alcance geral que fixa a CIDH ao Estado e que incluem, por exemplo, mudanças nas políticas públicas, na legislação e nos procedimentos judiciais e administrativos (CIDH, Maria da Penha Maia Fernandes v. Brasil, 2001a, Campo Algodonero: Claudia Ivette González, Esmeralda Herrera Monreal e Laura Berenice Ramos Monárrez v. México, 2007c).

A CIDH considerou especialmente o impacto diferenciado sobre certos grupos sociais de práticas disseminadas de violência realizadas por agentes estatais ou por atores não estatais com a conivência ou tolerância do Estado. Nesse sentido, a Comissão, por exemplo, impôs responsabilidade ao Brasil por não ter adotado medidas para prevenir desocupaçóes forçadas e violentas empreendidas por milícias privadas de fazendeiros, que expressavam um padrão sistemático de violência rural tolerado pelas autoridades estatais, acompanhado de um padrão de impunidade nas investigaçóes criminais desses fatos. Para isso, a CIDH levou especialmente em consideração a situação de desigualdade estrutural em que se encontra um setor da populaçáo rural em certos estados do Norte brasileiro e os níveis de aquiescência e conivência entre setores poderosos de fazendeiros, forças policiais e justiça estatal (CIDH, Sebastião Camargo Filho v. Brasil, 2009a). Em outro caso, a CIDH responsabilizou o Brasil por um padrão de violência policial dirigido a jovens negros nas favelas do Rio de Janeiro, considerando que a execução extrajudicial de um jovem desse grupo social era um fato representativo desse padrão, o qual, por sua vez, expressava uma tendência racista na atuaçáo da força policial estadual, com a cumplicidade da autoridade federal (CIDH, Wallace de Almeida v. Brasil, 2009b). Também a CIDH e a Corte IDH consideraram a situação de vulnerabilidade diferenciada diante da violência política de determinados grupos no marco do conflito armado interno na Colômbia, impondo ao Estado deveres específicos de proteção que implicam restriçóes ao uso da própria força estatal e proteção especial frente a outros atores não estatais, assim como obrigaçôes especiais de alcance coletivo e políticas sociais diferenciadas e culturalmente pertinentes. Essas medidas de proteção partem da obrigação de respeitar e garantir direitos culturais de grupos étnicos como, por exemplo, restriçóes a determinadas atividades bélicas em respeito à integridade dos territórios coletivos de povos indígenas e comunidades negras colombianas'.

Entre os setores mencionados pelo SIDH como grupos discriminados ou excluídos que requerem proteção especial ou tratamento diferenciado, encontramse os povos indígenas ${ }^{10}$ ou a população afrodescendente (FRY, 2002, ARIAS; YAMADA; TEJERINA, 2004) ${ }^{11}$ e as mulheres em relação ao exercício de certos direitos, como a integridade física ${ }^{12}$ e a participação política ${ }^{13}$. Também foi destacada a obrigação dos Estados de garantia diante da existência de grupos em situação de vulnerabilidade, como vimos, as crianças que vivem em situação de rua, ou em sistemas de internação, os doentes mentais em reclusão, os imigrantes indocumentados, a população rural desalojada de seu território, ou as pessoas pobres com HIV/Aids, entre outros.

Essa exposição sucinta indica que o SIDH não leva em consideração apenas uma noção formal de igualdade, limitada a exigir critérios de distinção objetivos e 
razoáveis e, portanto, a proibir diferenças de tratamento ilegítimas, voluntariosas ou arbitrárias, mas avança para um conceito de igualdade material ou estrutural, que parte do reconhecimento de que alguns setores da população estão em desvantagem no exercício de seus direitos em razão de obstáculos legais ou fáticos e requerem, por conseguinte, a adoção de medidas especiais de equiparação. Isso implica na necessidade de tratamento diferenciado quando, devido às circunstancias que afetam a um grupo em desvantagem, a forma de tratamento suponha restringir ou piorar o acesso a um serviço ou bem, ou o exercício de um direito. Ao mesmo tempo, obriga a examinar, num estudo de igualdade, a trajetória social da suposta vítima, o contexto social de aplicação das normas ou políticas questionadas, assim como a situação de subordinação ou desvantagem do grupo social ao qual pertencem os potenciais afetados ${ }^{14}$.

O emprego da noção de igualdade material implica na definição do papel do Estado como garantidor ativo dos direitos, em ambientes sociais de desigualdade. É ademais uma ferramenta útil para examinar as normas jurídicas, as políticas públicas e as práticas estatais, tanto sua formulação como seus efeitos. A imposição de obrigações positivas tem conseqüências muito importantes a respeito do papel político ou promocional do SIDH, pois impóe aos Estados o dever de formular políticas para prevenir e reparar violaçóes de direitos humanos que afetam a certos grupos ou setores menosprezados.

Além disso, tem conseqüências diretas no debate sobre disponibilidade de garantias judiciais, pois sabe-se que as obrigações positivas são mais difíceis de exigir nos sistemas domésticos de justiça, em especial quando se exigem comportamentos positivos para solucionar conflitos de natureza coletiva.

Também as obrigaçôes positivas entram em tensão com as capacidades estatais dos Estados americanos. O SIDH foi gradualmente adicionando aos Estados cada vez mais deveres de prevenção de violaçóes e de proteção dos direitos diante da ação de atores não estatais em algumas circunstâncias determinadas. Essa ampliação do conjunto de obrigações estatais coloca em evidência a discrepância entre as expectativas depositadas pelo SIDH nos Estados e a realidade marcada pela debilidade das instituiçôes e ineficácia das políticas. Para alcançar os exigentes standards do SIDH em matéria de obrigações positivas, são necessárias instituições com capacidade de planejamento e gestão de políticas que disponham de recursos humanos e financeiros adequados. Daí que começa a assinalar com maior nitidez uma crescente brecha entre o discurso normativo e as capacidades reais de satisfação das obrigaçóes impostas.

As obrigações positivas se fixaram também no SIDH em relação ao exercício do direito à participação dos povos indígenas que envolvem, entre outras questôes, a possibilidade de exercer seu direito à consulta prévia, livre e informada, a respeito das políticas que possam afetar seus territórios comunais, como exploraçôes econômicas e de recursos naturais, e a dialogar com as instâncias do Estado e outros atores sociais por meio de suas próprias representaçóes políticas (AYLWIN, 2004). Nesse tema, observa- se a vinculação direta entre o exercício de direitos culturais e sociais com direitos civis e políticos, pois a base da argumentação é o vínculo especial que têm os povos indígenas com seus territórios e recursos, o que considera não apenas interesses econômicos, mas também a preservação de sua identidade cultural 
e a própria existência de uma cultura ${ }^{15}$. Esses direitos previstos em instrumentos internacionais, tais como a Convenção 169 da OIT, também foram reconhecidos com base na própria Convenção Americana, a partir de uma leitura na perspectiva social do artigo 21, que consagra o direito de propriedade. Numa série de decisóes, a Corte Interamericana estabeleceu a obrigação dos Estados de dispor de mecanismos adequados para a participação, produção de informação sobre impactos social e ambiental, e consulta para busca de consentimento dos povos indígenas naquelas decisóes que possam afetar o uso de seus recursos naturais ou alterar seus territórios Nesse sentido, trata-se do reconhecimento de faculdade de participação diferenciada em decisôes de políticas públicas do Estado nacional, mas que ao mesmo tempo define mais que um direito processual e alcança o reconhecimento de um "direito especial do grupo" para preservar uma esfera de autogoverno ou de autonomia nessas questóes (CORTE IDH, Comunidade Mayagna (Sumo) Awas Tingni, 2001, CORTE IDH, Massacre de Plan Sanchez v. Guatemala, 2004, Comunidade Moiwana v. Suriname, 2005a, CORTE IDH, Comunidade Indígena Yakye Axa v. Paraguai, 2005b, CORTE IDH, Povo Saramaka v. Suriname, 2007). Embora a jurisprudência do SIDH tenha estabelecido que não se trata de um poder de veto a favor dos povos indígenas, refere-se, sem dúvida, a um dos campos mais conflituosos dentre os temas abordados pelo SIDH na atualidade, pois aqui se observa com maior nitidez a tensão entre o reconhecimento de um direito diferenciado a favor de uma coletividade e o interesse público envolvido em certas estratégias de desenvolvimento econômico dos governos nacionais.

Em decisão recente, a Corte Interamericana de Direitos Humanos estabeleceu a obrigação dos Estados de adotar medidas positivas para garantir que os povos e as comunidades indígenas possam participar, em condiçôes de igualdade, na tomada de decisóes sobre assuntos e políticas que incidam ou possam incidir em seus direitos e no desenvolvimento de tais comunidades, de tal forma que possam integrar-se a instituiçóes e órgãos estatais e participar de maneira direta e proporcional a suas populaçóes na condução dos assuntos públicos, assim como fazê-lo desde suas próprias instituiçóes políticas e de acordo com seus valores, usos, costumes e formas de organização. A Corte, na sentença proferida no caso Yatama (CORTE IDH, Yatama v. Nicarágua, 2005c $)^{16}$, considerou que a legislação nicaragüense sobre o monopólio de partidos políticos e as decisóes dos órgãos eleitorais do Estado haviam limitado demasiadamente a possibilidade de participação num processo eleitoral de uma organização política representativa das comunidades indígenas da costa atlântica do país. Esse caso, também em nossa opinião, demonstra a afirmação do princípio da igualdade estrutural, pois a Corte IDH determina ao Estado flexibilizar a aplicação das normas eleitorais de alcance geral para adequá-las às formas de organização política que expressem a identidade cultural de um grupo. Ao final, o que a Corte reconhece é um "direito especial ou diferenciado a favor de um grupo" (KYMLICKA, 1996, 1999) que fixa certas “proteçóes externas” ao grupo minoritário, que se consideram indispensáveis para a preservação de sua autonomia, mas também sua participação nas estruturas internas do próprio Estado.

Também se fixou no SIDH fortes obrigaçóes positivas em relação ao direito de acesso à justiça que resultam em outra repercussão nesse campo da referida 
noção de igualdade material. O SIDH fixou standards bastante precisos sobre o direito a recursos judiciais e de outra natureza que se mostrem idôneos e efetivos para demandar em casos de violação dos direitos fundamentais. Nesse sentido, a obrigação do Estado não é apenas negativa (de não impedir o acesso a tais recursos), mas fundamentalmente positiva, de organizar o aparato institucional de modo que todos, especialmente aqueles que se encontrem em situação de pobreza ou exclusão, possam acessar esses recursos; para tanto deverá remover os obstáculos sociais ou econômicos que dificultem ou limitem a possibilidade de acesso à justiça, mas além disso o Estado deverá organizar um serviço público de assistência juridica gratuita e mecanismos para aliviar o custo dos processos e torna-los viáveis, por exemplo, estabelecendo sistemas para eximir gastos. ${ }^{17}$ As políticas que buscam garantir serviços jurídicos a pessoas carentes de recursos atuam como mecanismos para compensar situaçóes de desigualdade material que afetam a defesa eficaz dos próprios interesses e, por isso, são políticas judiciais que relacionam com as políticas sociais. O SIDH fixou a existência de um dever estatal de organizar esses serviços para compensar situaçóes de desigualdade real e garantir a paridade de armas num processo judicial. Determinou, além disso, algumas obrigaçóes concretas de devido processo que se aplicam em relação aos procedimentos judiciais de natureza social, como os juízos trabalhistas e previdenciários e as ações de amparo e desocupação. Recentemente, fixou alguns indicadores para avaliar o cumprimento dessas obrigações pelos Estados (CIDH, 2007a ${ }^{18}$.

Essa base de obrigaçóes positivas impostas aos Estados, vinculada ao reconhecimento de um cenário de desigualdade que caracteriza a realidade americana, serve em determinadas ocasióes como marco para o exame das políticas públicas nos relatórios temáticos e de país, como fora mencionado anteriormente, e é uma ferramenta central para o trabalho promocional dos órgãos do SIDH.

\section{A efetividade das decisóes. A articulaçáo com os sistemas locais de justiça}

A autoridade das decisóes e da jurisprudência dos órgãos do Sistema depende em parte da legitimidade social alcançada e da existência de uma comunidade de atores interessados que acompanha e difunde seus parâmetros e decisóes. Não se trata de incidir por meio de força coativa, da qual carece, mas de uma força persuasiva que deve construir e preservar.

Assim, nos países nos quais o direito internacional dos direitos humanos faz parte cotidianamente do discurso jurídico e dos argumentos apresentados nas Cortes, dão-se alguns fatores que nos parece apropriado ressaltar. Por um lado, o SIDH ganhou legitimidade por estar vinculado a momentos relevantes dos processos políticos do país, especialmente a resistência às ditaduras e reconstrução da ordem constitucional e democrática. Por outro lado, e em parte por causa disso, existe uma comunidade de atores sociais, políticos e setores acadêmicos que se consideram protagonistas da evolução do próprio SIDH e participam ativamente do processo de implementação nacional de suas decisôes e princípios.

Muitos países da América Latina ratificaram tratados de direitos humanos e 
se integraram ao SIDH na etapa das transiçóes para a democracia, como uma forma de antídoto para afastar o risco de retrocessos autoritários, unindo seus sistemas políticos e legais ao "mastro" da proteção internacional ${ }^{19}$. Abrir os assuntos de direitos humanos ao escrutínio internacional foi uma decisão funcional aos processos de consolidação da institucionalidade durante as transições, pois contribuiu para ampliar as garantias dos direitos fundamentais num sistema político demarcado por atores militares com poderes de veto, e pressóes autoritárias ainda poderosas ${ }^{20}$.

$\mathrm{Na}$ Argentina, por exemplo, a ratificação dos tratados de direitos humanos se deu em 1984, no início da transição democrática. A incorporação dos tratados de direitos humanos com hierarquia constitucional em 1994 foi um importante passo nesse processo. Mas também foi o papel desempenhado pela Comissão em sua visita ao país em plena ditadura militar em 1979, e seu relatório, que contribuiu para fortalecer as organizaçóes de vítimas e para desgastar o governo perante a comunidade internacional. No Peru, foi central a legitimidade adquirida pela Comissão e pela Corte em suas consideraçóes sobre as violações de direitos humanos durante o governo de Fujimori. A visita da CIDH ao Peru em 1992, e depois em 1999, e seu relatório sobre "democracia e direitos humanos", junto com as sentenças paradigmáticas da Corte sobre legislação antiterrorista, liberdade de expressão e tribunais militares, contribuíram para documentar e expor a gravidade das violações cometidas durante esse período. O pleno retorno do Peru ao SIDH em 2001 e a aceitação da responsabilidade internacional pelos crimes atrozes do regime de Fujimori compuseram uma política essencial do governo de transição. Isso certamente contribuiu para configurar um setor de organizaçóes sociais, de acadêmicos, assim como um núcleo de juízes e operadores do direito familiarizados com o sistema.

Embora na última década se tenha avançado substancialmente na incorporação do direito internacional dos direitos humanos no direito interno dos Estados e em diversos países da região, a jurisprudência da Corte é considerada como um guia, e inclusive como um "guia inescusável” para a interpretação da Convenção Americana pelos juízes locais ${ }^{21}$, não se trata de um processo linear e existem vozes dissidentes.

Recentes decisóes dos tribunais superiores na República Dominicana e na Venezuela menosprezam a obrigatoriedade das decisóes da Corte IDH e procuram resguardar para as Cortes nacionais uma faculdade de revisão prévia (teste de legalidade) sobre a compatibilidade da decisão do órgão internacional com a ordem constitucional do país. Trata-se de um debate em aberto nos sistemas de justiça do continente, em que as posiçóes refratárias à incorporação do direito internacional dos direitos humanos têm ainda um peso considerável que, com variaçóes, expóem argumentos que indicam o resguardo de maior autonomia nacional.

O exame jurídico dessas sentenças excede as pretensóes deste artigo. No entanto, advertimos que frequentemente certas posiçôes que criticam a crescente limitação da autonomia política dos Estados nacionais em matéria de direitos humanos costumam partir de uma visão simples ou esquemática do processo de elaboração de normas internacionais e de sua aplicação no âmbito doméstico. Por um lado, minimizam a importância da participação de atores sociais ou instituiçóes locais na criação de normas e parâmetros internacionais de direitos humanos. Por outro lado, consideram a 
aplicação doméstica como se fosse uma imposição externa ao sistema político e jurídico nacional, sem considerar que essa incorporação só é possível pela ativa participação de atores sociais, políticos e judiciais relevantes, assim como pela construção gradual de consensos nos diversos âmbitos institucionais. Daí que costumam marcar linhas divisórias definidas entre a esfera internacional e a doméstica, quando a dinâmica de atuação dos mecanismos internacionais evidencia que essa fronteira é muito mais imprecisa e que existe uma constante articulação e relação entre a esfera local e internacional, tanto na elaboração como na interpretação e aplicação de normas de direitos humanos. Assim, atores sociais e políticos locais relevantes costumam participar dos processos de elaboração de normas na esfera internacional, tanto da aprovação e ratificação de tratados como nas decisóes de órgãos internacionais que definem seu conteúdo por via de interpretação e sua aplicação em casos ou situaçóes específicas. Ao mesmo tempo, essas normas internacionais se incorporam no âmbito nacional pela ação dos Congressos, governos, sistemas de justiça e também com a participação ativa de organizaçóes sociais que promovem, demandam e coordenam essa aplicação nacional com as diversas instâncias do Estado. A aplicação de normas internacionais no âmbito nacional não é um ato mecânico, mas um processo que envolve também diferentes tipos de participação e deliberação democrática e inclui uma ampla margem para a releitura ou reinterpretação dos princípios e normas internacionais em função de cada contexto nacional ${ }^{22}$.

Em relação ao SIDH, como vimos nos pontos 2 e 3 deste artigo, atualmente, diferente do período das ditadura, sua intervenção em determinados assuntos domésticos pode obedecer a relaçóes de coordenação ou articulação com diversos atores locais, públicos e sociais, que participam tanto da formulação das demandas perante a instância internacional, quanto dos processos de implementação de suas decisóes específicas ou de seus standards gerais no âmbito interno ${ }^{23}$. Daí que sempre resultasse difícil conceituar sua intervenção como uma simples limitação da margem de autonomia dos processos políticos nacionais. $\mathrm{O}$ jogo da intervenção internacional nesse cenário é variado e complexo, mas em geral conta com o apoio de fortes atores locais que estimulam a resposta internacional e depois potencializam seus efeitos no âmbito doméstico. Algumas vezes, por exemplo, o SIDH se apóia na sociedade civil para fiscalizar o governo da maneira tradicional ${ }^{24}$; mas também pode atuar de maneira coordenada com os governos federais para alcançar a implementação de medidas ou políticas em nível estadual local ou provincial ${ }^{25}$; em algumas ocasióes se apóia em decisóes ou precedentes dos tribunais para ter padróes de acompanhamento das açóes do Congresso ou do governo ${ }^{26}$; ou os governos ou os Congressos solicitam sua intervenção para contribuir para alcançar consensos com outros poderes como o Judiciário ${ }^{27}$ ou acompanhar a implementação de medidas que têm resistência dos atores locais sociais ou políticos ${ }^{28}$. Usualmente, os tribunais locais apóiam-se nas decisóes do SIDH para controlar as políticas dos governos ou do Congresso ${ }^{29}$. Vimos também como em certos casos, especialmente nos processos de negociação ou de "solução amistosa", o jogo de alianças é ainda mais complexo, inclusive órgãos públicos são usuários do $\mathrm{SIDH}$ às vezes em parceria com organizações sociais, procurando estimular o escrutínio internacional sobre determinadas questôes. Com esse breve comentário não pretendemos negar a importância de 
preservar a autonomia política dos Estados para decidir determinadas matérias, mas simplesmente relativizar certas interpretaçôes esquemáticas sobre como funciona na realidade um sistema de justiça internacional e como se relaciona com os processos políticos nacionais.

Um fator importante para a consolidação de uma maior abertura dos sistemas nacionais de justiça para a aplicação do direito internacional é a configuração de uma forte comunidade acadêmica, que discuta criticamente as decisóes do sistema e contribua com insumos para a utilização da jurisprudência pelos juízes e operadores do direito. Essa comunidade acadêmica local e regional não só é indispensável para assegurar a aplicação dos standards interamericanos em nível doméstico, mas também para obrigar a prestar contas aos próprios órgãos do SIDH e pressionar por uma melhoria na qualidade, consistência e rigor técnico de suas decisóes. Embora existam avanços evidentes nos últimos tempos, ainda não é possível afirmar que essa comunidade exista em nível regional. As decisóes da Corte e da Comissão são pouco comentadas, muito pouco criticadas e em vários países raramente conhecidas. Os debates tímidos originados nos últimos tempos provocaram a reformulação, ao menos a nível teórico, de algumas premissas. Apenas como exemplo é interessante expor os questionamentos que são formulados pela dogmática penal tradicional sobre o alcance dos deveres de persecução penal de graves violaçóes de direitos humanos estabelecidos na jurisprudência do SIDH e suas conseqüências sobre algumas garantias dos acusados, como o princípio da coisa julgada e ne bis in idem (MARGARELL; FILIPPINI, 2006), assim como as discussóes que parte $\mathrm{da}$ doutrina constitucional formula sobre o valor da autoridade das decisóes de um órgão internacional de direitos humanos questionando o déficit democrático desses órgãos internacionais ou a falta de conhecimento dos processos que se dão no interior das comunidades políticas nacionais (GARGARELLA, 2008) ${ }^{30}$.

É verdade que o grau de cumprimento das decisóes do SIDH é importante em relação às medidas reparatórias e também a respeito das medidas de reformas legislativas que foram já mencionadas. Em ambos casos, alguns estudos preliminares sugerem que o maior grau de cumprimento se dá nos processos de solução amistosa, quando o Estado de maneira autônoma assume compromissos dessa natureza.

No entanto, os principais problemas de descumprimento tanto das recomendaçóes da CIDH quanto das sentenças da Corte IDH estão nas medidas de investigação penal de crimes de estado, particularmente quando os processos internos tenham sido arquivados e sua reabertura pode afetar as garantias dos acusados. Em alguns países, observa-se uma grave deterioração das instâncias judiciais com níveis de impunidade generalizados, isto é, que não se limitam aos casos de violaçóes de direitos humanos. Vimos como o SIDH utilizou a análise de padróes estruturais de impunidade para invalidar decisóes judiciais que pretendem encerrar a investigação desse tipo de crimes geralmente para beneficiar grupos com poder e em prejuízo de determinadas vítimas ${ }^{31}$.

Não se avançou de maneira significativa nos mecanismos internos de implementação das decisões dos órgãos do $\mathrm{SIDH}^{32}$. Isso particularmente se torna um obstáculo quando se trata da imposição de obrigaçóes positivas. $\mathrm{O}$ trâmite de um caso internacional e o cumprimento das medidas de reparação fixadas exigem um 
alto grau de coordenação entre diferentes órgãos do governo, o que não se costuma alcançar. Isso dificulta sensivelmente o trâmite do caso, o trabalho dos órgãos do SIDH e o cumprimento das decisóes. A coordenação no interior do próprio governo é complexa, mas é ainda mais complexa a coordenação do governo com o Parlamento ou a Justiça, quando as medidas envolvidas no caso requerem reformas legais ou a ativação de processos judiciais. O tema é ainda mais grave quando se trata de coordenar órgãos federais com Estados provinciais em sistemas federados.

A Comissão e a Corte elaboram um relatório para a Assembléia da OEA sobre os descumprimentos, mas o tempo que tem para expor a situação e demandar os mecanismos de garantia coletiva dos Estados é mínimo. Tampouco existe um debate aprofundado no âmbito do sistema sobre como melhorar os mecanismos de cumprimento de natureza política e alcançar maior compromisso dos diversos órgãos da OEA.

O mecanismo mais efetivo até agora para obter resultados no cumprimento é a criação de instâncias de supervisão internacional como as audiências de seguimento perante a Comissão ou Corte. Muitas organizaçôes que representam vítimas preferem esses mecanismos de supervisão internacional aos sistemas internos de execução, pois entendem que retornar ao âmbito nacional implica às vítimas restabelecer uma situação de desequilíbrio de poder com o Estado que só a participação do órgão internacional pode evitar (ABREGÚ; ESPINOZA, 2006).

Outro ponto a se considerar quando se examinam os obstáculos para a efetividade do sistema é o tipo de garantias que se dispóem como medidas de reparação nos casos contenciosos ou nas medidas cautelares ou provisórias. Muitas vezes, as garantias fixadas nos casos obedecem às sugestóes dos peticionários ou representantes das vítimas e não há uma corrente jurisprudencial consistente sobre isso. Outro problema é que o sistema segue pensando e desenhando garantias sob o modelo elaborado no período das transiçóes, colocando mais ênfase na investigação e determinação de responsáveis pelas violaçóes e menos na modificação dos problemas estruturais que essas violaçóes evidenciam. Esse sistema de garantias clássicas não se enquadra plenamente no tipo de conflitos próprios da nova agenda a que fazíamos referência. Sobretudo quando o SIDH não se limita a julgar fatos ocorridos no passado, mas procura prevenir a consumação de danos, o agravamento de situações em curso, ou pretende incidir na reversão de padróes sistemáticos ou superar deficiências institucionais. Isso ficou exposto, na minha opiniáo com maior evidência, nas medidas provisórias da Corte em matéria prisional. Esses assuntos, nos quais se demonstra a existência de condiçóes desumanas de detenção e práticas estruturais de violência toleradas pelas autoridades estaduais e federais, funcionam como uma forma de "habeas corpus" coletivo internacional. Neles se desenvolveu um interessante debate sobre o tipo de garantias e mecanismos de supervisão internacionais e locais. A Corte, a pedido dos peticionários e da Comissão, foi modificando gradualmente o tipo de garantias impostas ao Estado federal e por seu intermédio aos Estados provinciais, mas ainda não se conseguiu um cumprimento adequado das ordens estabelecidas. A lógica das garantias fixadas se assemelha às garantias do litígio de reforma estrutural nos tribunais nacionais. Nesse tipo de casos, procura-se equilibrar numerosos interesses contrapostos e dar ao governo 
uma margem para definir medidas, apresentando planos de ação de médio e longo prazo. Busca-se ademais resguardar o acesso à informação e a participação das vítimas e seus representantes nos processos que definem essas políticas (SABEL; SIMON, 2004, GAURI; BRINKS, 2008, ABRAMOVICH, 2009). Uma discussão em aberto é se essas medidas de supervisão internacional podem ser efetivas sem que se envolva ativamente o próprio sistema doméstico de justiça e órgáos públicos nacionais que estejam em condiçóes de realizar uma avaliação e fiscalização da situação penitenciária permanente no local ${ }^{33}$.

A persistência do baixo grau de efetividade desses remédios estruturais pode conduzir a uma reformulação de todo o SIDH e trazer custos em termos de legitimidade da Corte. O certo é que o SIDH ingressou numa etapa de desenvolvimento de um modelo de litígio estrutural de proteção de grupos ou coletividades, sem ter aperfeiçoado e discutido com profundidade os limites ou potencialidades de suas regras processuais ${ }^{34}$, seu sistema de garantias e seus mecanismos de seguimento e supervisão de decisóes.

O debate sobre a efetividade da supervisão internacional está relacionado diretamente a uma questão vital para a qualidade dos processos democráticos, que é a baixa atuação dos sistemas locais de justiça.

No Gráfico a seguir observa-se uma análise temática do total de petições recebidas pela $\mathrm{CIDH}$ em 2008, em que se verifica claramente o lugar central que ocupam os problemas relacionados com o funcionamento dos sistemas judiciais nacionais: em torno de $62 \%$ das denúncias se referem a esse tema. Dentro da questão justiça, 23\% denuncia violaçôes de devido processo em âmbito penal, 15\% em matéria trabalhista e $9 \%$ em processos administrativos.

\section{PETIÇÕES DE 2008 EM ANDAMENTO, POR TIPO DE VIOLAÇÃO ALEGADA}

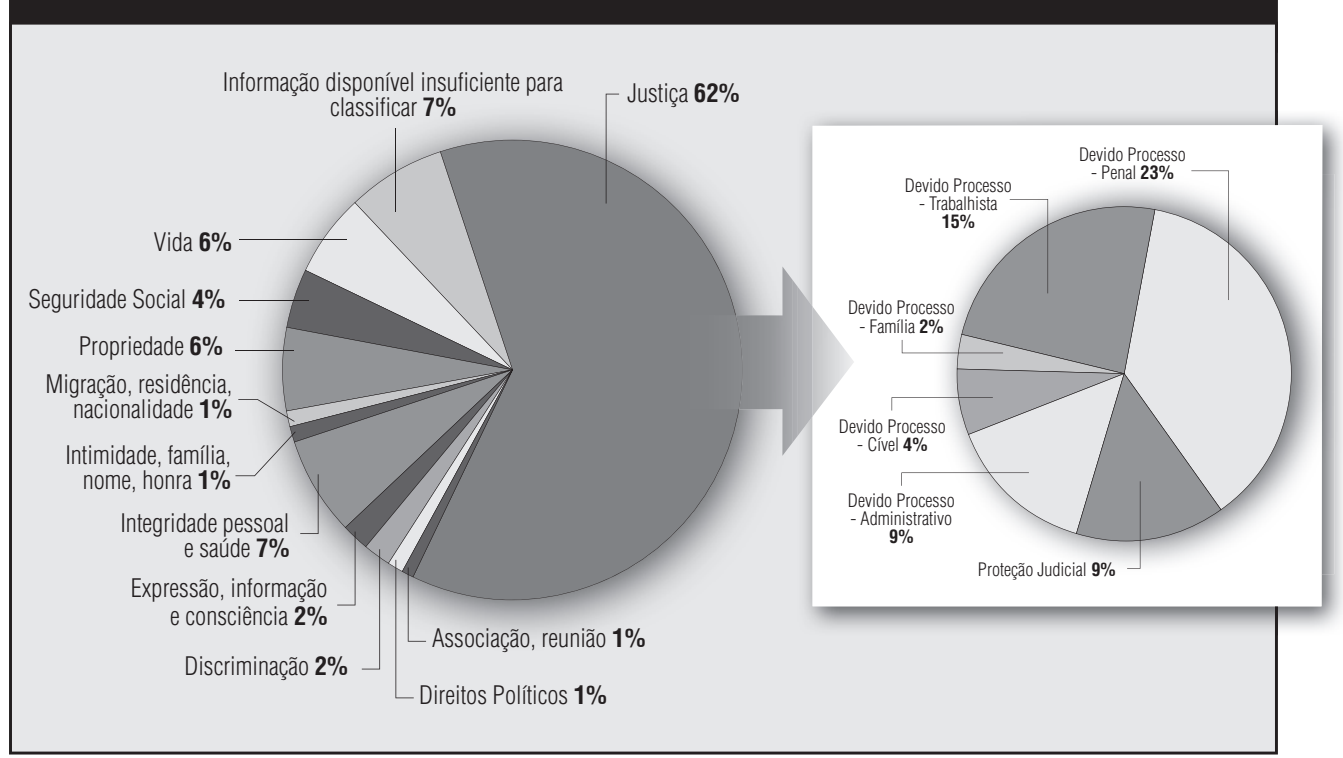

Fonte: elaboração própria, com base em dados fornecidos pela CIDH 
Não há dúvidas de que uma estratégia central para melhorar a efetividade do SIDH é trabalhar em aperfeiçoar a resposta dos sistemas nacionais de administração da justiça. O SIDH deu passos importantes nesse caminho ao fixar alguns princípios definidos sobre o que se entende por tribunais independentes ou imparciais, prazo razoável dos processos, uso excepcional da prisão preventiva, o alcance da coisa julgada, a revisáo judicial de decisóes administrativas, entre outros temas. Uma melhor sistematização dessa jurisprudência poderia servir como marco orientador das políticas de reforma judicial na região, melhorando a tutela dos direitos nos sistemas judiciais locais. O seguimento dos sistemas judiciais nacionais ocupa um espaço prioritário da agenda de supervisão política da CIDH, o que se pode concluir a partir da temática e seus recentes relatórios e documentos.

O desenvolvimento de obrigaçóes de fazer no campo dos direitos humanos, assim como de direitos que podem apresentar uma dimensão coletiva, exige ao mesmo tempo determinar com maior precisão o que se deve entender por recursos idôneos e efetivos para protegê-los. Um sistema adequado e acessível de ações coletivas, como amparos coletivos, mandados de segurança, açóes de classe e de mecanismos de proteção cautelar urgente, pode promover um litígio local de interesse público que permita dirimir nos tribunais nacionais muitos dos conflitos que hoje se resolvem no cenário internacional. A promoção de mecanismos judiciais para o litígio local de interesse público, em temas de direitos humanos, é portanto também estratégica para o SIDH.

\section{Conclusão}

Não restam dúvidas de que o SIDH conta com importante legitimidade, originada em seu trabalho de desestabilização das ditaduras e, depois, em seu papel inverso, no acompanhamento dos processos de transição para a democracia. Neste artigo expomos que no atual cenário política da América Latina, o valor estratégico do SIDH consiste em sua contribuição para o fortalecimento das instituiçóes democráticas, especialmente a justiça, e para os esforços nacionais para superar os atuais níveis de exclusão e desigualdade. Para tanto, além da consolidação de sua jurisprudência e do desenvolvimento de seu sistema de petiçóes individuais, o SIDH deve considerar seu papel político, colocando em foco os padróes estruturais que afetam o exercício efetivo dos direitos pelos grupos subordinados da população. Para isso deverá resguardar sua função subsidiária dos sistemas nacionais de proteção e buscar que seus princípios e parâmetros se incorporem náo apenas na doutrina dos tribunais, mas na orientaçáo geral das leis e nas políticas de governo. 


\section{REFERÊNCIAS}

\section{Bibliografia e outras fontes}

ABRAMOVICH, V. 2009. El Rol de la Justicia en la articulación de políticas y derechos sociales. In: ; PAUTASSI, L. (Org). La Revisión Judicial de las Políticas Sociales. Estudio de casos. Buenos Aires: Editores del Puerto, p. 1-91. BOVINO, A.; COURTIS, C. 2006. La Aplicación de los Tratados sobre Derechos Humanos en el Ambito local. La Experiencia de una Década. Buenos Aires: CELS, Editores del Puerto.

ABREGU, M.; ESPINOZA, O. 2006. La Eficacia de la Comisión Interamericana de Derechos Humanos y la Aplicación de sus Decisiones por los Estados Parte. In: ABRAMOVICH, V.; BOVINO, A.; COURTIS, C. La Aplicación de los Tratados sobre Derechos Humanos en el Ambito local. La Experiencia de una Década. Buenos Aires: CELS, Editores del Puerto, p. 191-216.

ANAYA, J. S. 2005. Los Pueblos Indígenas en el Derecho Internacional. Madrid: Editorial Trotta, Universidad Internacional de Andalucía.

ARIAS, O.; YAMADA, G.; TEJERINA, L. 2004. Ingresos y color en Brasil: una historia compleja. In: BUVINIC, M.; MAZZA, J.; PUNGILUPPI, J.; DEUTSCH, R. Inclusión Social y desarrollo económicos en América Latina. Washington, D.C.: Banco Interamericano de Desenvolvimento, p. 215-236.

AYLWIN, J. 2004. Derechos Humanos y derechos indígenas en América del Sur: antecedentes, movimientos y desafíos. In: ZALAQUETT, José. Temas de Derechos Humanos en Debate. Lima: IDL, Centro de Derechos Humanos Facultad de Derecho de la Universidad de Chile, p. 153-222.

BOHMER, M. 2007. "Prestamos y Adquisiciones. La utilización del derecho extranjero como una estrategia de creación de autoridad democrática y constitucional”. Disponível em: <http://www.law.yale.edu/documents/pdf/sela/ MartinBohmer__Spanish_.pdf>. Último acesso em: Nov. 2009.

CENTRO DE ESTUDIOS LEGALES Y SOCIALES (CELS). 2007. La Aplicación de los Tratados sobre Derechos Humanos en el Ambito local. La Experiencia de una Década. Buenos Aires: CELS, Editores del Puerto.

COMISSÃO INTERAMERICANA DE DIREITOS HUMANOS (CIDH). 2003. Justicia e Inclusión Social. Los Desafíos de la democracia en Guatemala. OEA/ Ser.L/V/II.118. Doc. 5 rev. 1, 29 Dezembro. 2006a. Informe sobre la Situación de los Defensoras y Defensores de Derechos Humanos en las Américas. OEA/Ser.L/V/II.124. Doc. 5 rev.1, 7 Março. 2006b. Las Mujeres frente a la Violencia y la Discriminación derivadas del Conflicto Armado en Colombia. OEA/Ser.L/V/II. Doc. 67, 18 Outubro. 2007a. El Acceso a la Justicia para las Mujeres Víctimas de Violencia en las Américas. OEA/Ser.L/V/II. Doc. 68, p. 33-51, 20 de Janeiro. 
2007b. Capítulo IV: Desarrollo de los Derechos Humanos en la Región -

Colombia. In: . Relatório Anual da Comissão Interamericana de Direitos Humanos 2006. EA/Ser.L/V/II.127. Doc. 4 rev. 1, 3 Março.

2007c. El Acceso a la Justicia como Garantía de los Derechos Económicos, Sociales y Culturales. Estudio de los Estándares fijados por el Sistema Interamericano de Derechos Humanos. OEA/Ser.L/V/II.129. Doc. 4, 7 Setembro. 2007d. Acceso a la Justicia e Inclusión Social. El Camino hacia el Fortalecimiento de la Democracia en Bolivia. 28 de junio. Washington: CIDH. Disponível em: <http://www.cidh.org/countryrep/Bolivia2007sp/Bolivia07indice. sp.htm>. Último acesso em: Nov. 2009.

2007e. Capítulo IV: Desarrollo de los Derechos Humanos en la Región Colômbia. In: . Relatório Anual da Comissão Interamericana de Direitos Humanos 2007. OEA/Ser.L/V/II.130. Doc. 22 rev. 1, 29 Dez. 2008a. CIDH expressa preocupação com extradição de paramilitares. Comunicado de Imprensa 21/08. Washington D.C., EEUU, 14 Maio. 2008b. CIDH termina sua visita à Bolívia. Comunicado de Imprensa 26/08. La Paz, Bolívia, 13 Jun.

2008c. Lineamientos para la Elaboración de Indicadores de Progreso en materia de Derechos Económicos, Sociales y Culturales. OEA/Ser.L/V/II.132, Doc. 14 rev. 1,19 Jul.

2008d. Informe sobre la visita al terreno en relación con las medidas provisionales ordenadas a favor de los miembros de las comunidades constitutitas por el Consejo Comunitario del Jiguamiandó y las familias del Curbaradó, Municipio del Carmen del Daríen, Departamento del Chocó, República de Colombia. Disponível em: <http://www.cidh.org/countryrep/MPColombia2.20.09. sp.htm>. Último acesso em: Nov. 2009.

2009a. El Derecho de las Mujeres a una Vida Libre de Violencia y Discriminación en Haití. OEA/Ser.L/V/II, Doc. 64, 10 Mar.

2009b. Informe sobre los Derechos de las Mujeres en Chile: La Igualdad en la Familia, el Trabajo y la Política. OEA/Ser.L/V/II.134, Doc. 63, 27 Mar.

ELSTER, J. 1979. Ulises y las sirenas: estudios sobre racionalidad e irracionalidad. Mexico: Fondo de Cultura Económica.

FARER, T. 1998. The Future of the Inter-American Comisión on Human Rights: Promotion versus Exposure. In: MENDEZ, Juan; COX, Francisco (Ed.). El Futuro del Sistema Interamericano de Protección de los Derechos Humanos. San José: IDH, p. 515-536.

FERRAJOLI L. 1999. Igualdad y Diferencia. In: del más débil. Madrid: Editorial Trotta, p. 73-96. Derechos y garantías. La ley

FILIPPINI, L. 2007. El Derecho Internacional de los derechos humanos no es un préstamo. Reflexiones sobre la crítica a los préstamos de Carlos F. Rosenkrantz. Revista Jurídica de la Universidad de Palermo, v. 8, n. 1, Set., p. 191-213. 
FISS, O. 1999. Grupos y la Cláusula de Igual protección. In: GARGARELLA, R. (Org.). Derecho y grupos desaventajados. Gedisa Editorial: Barcelona, p. 137-167.

FRY, P. 2002. Color e imperio de la ley en Brasil. In: MENDEZ, J.; ODONELL, G.; PINHEIRO, P. S. (Org.). La (in)efectividad de la ley y la exclusión en América Latina. Buenos Aires, Barcelona, Mexico: Paidos, p. 191-212.

GARCIA AÑON, J. G. 1997. Current Problems of Legal Dogmatics in European Regulation: The principle of Equality and the Policies of Affirmative Action. In: BARRERE UNZUETA, M. Discriminación, Derecho Antidiscriminatorio y Acción Positiva a favor de las mujeres. Madrid: Civitas.

GARGARELLA, R. 2008. Justica Penal Internacional y Violaciones Masivas de Derechos Humanos. In: De la Injusticia Penal a la Justicia Social. Bogota: Universidad de Los Andes, Siglo del Hombre Editores.

GAURI, V.; BRINKS, D. M. 2008. A New Policy Landscape: Legalizing Social and Economic Rights in the Developing World. In: (Ed.). Courting Social Justice: Judicial Enforcement of Social and Economic Rights in the Developing World. New York: Cambridge University Press.

KAHN, P. W. 2002. El Derecho Internacional y la Comunidad. In: Estado de Derecho y Democracia. Un debate sobre el rule of law”. Buenos Aires: Editores del Puerto.

KOH, H. H. 1996. Transnational Legal Process. Nebraska Law Review, v. 75, p. 181. . 1997. Why do Nations Obey International Law?. Yale Law Journal, v. 106, p. 2599. . 2004. International Law as Part of Our Law. American Journal of International Law. v. 98, n. 1, p. 43.

KRSTICEVIC, Viviana. 2007. Reflexiones sobre la Ejecución de las Decisiones del Sistema Interamericano de Protección de Derechos Humanos. In: TOJO, L.; KRSTICEVIC, V (Ed.). Implementación de las Decisiones del Sistema Interamericano de Derechos Humanos. Jurisprudencia, Normativa y Experiencias Nacionales". Buenos Aires: CEJIL, p. 15-112.

KYMLICKA, W. 1996. Ciudadanía Multicultural. Barcelona: Paidos. 1999. Nacionalismo Minoritario dentro de las Democracias Liberales. In: GARCIA, S.; LUKES, S. Ciudadanía: Justicia Social, Identidad y Participación. Madrid: Siglo XXI Editores.

MACDOWELL SANTOS, C. 2007. Activismo jurídico transnacional e o Estado: reflexôes sobre os casos apresentados contra o Brasil na Comissão Interamericana de Directos Humanos. Sur - Revista Internacional de Direitos Humanos, ano 4, n. 7.

MARGARELL, L.; FILIPPINI, L. (Ed.). 2006. El Legado de la Verdad. La Justicia Penal en la Transición Peruana. Lima: International Center for Transitional Justice (ICTJ), Instituto de Democracia y Derechos Humanos (IDEHPUCP).

MENDEZ, J. E.; MARIEZCURRENA, J. 2000. "Human Rights in Latin America and The Caribean: A Regional Perspective”. Disponível em: <http://hdr.undp.org/en/ reports/global/hdr2000/papers/mendez2000.pdf> Último acesso em: Nov. 2009. 
MORAVCSIK, A. 2000. The Origins of Human Rights Regimes: Democratic Delegation in Postwar Europe. International Organization, v. 54, n. 2, p. 217-249, Primavera.

NELSON P.; DORSEY, E. 2006. New Rights Advocacy in a Global Public Domain. European Journal of International Relations, Junho.

PINHEIRO, P. S. 2002. La Efectividad de la ley y los Desfavorecidos en América Latina. In: .; MENDEZ, Juan E.; O’DONNELL, Guillermo A.; La (In)efectividad de la Ley y la Exclusión Social en América Latina. Buenos Aires: Paidos, p. 15-31.

ROSENKRANTZ, C. F. 2005. En contra de los "Préstamos" y otros usos "no autoritativos" del derecho extranjero. Revista jurídica de la Universidad de Palermo, v. 6, n. 1, p. 71-95, Outubro. 2007. Advertencias a un internacionalista (o los problemas de Simón y Mazzeo). Revista Jurídica de la Universidad de Palermo, v. 8, n. 1, p. 191, Setembro.

SABA, R. P. 2004. (Des)igualdad estructural. In: AMAYA, Jorge (Ed.). Visiones de la Constitución 1853-2004. Buenos Aires: UCES, p. 479-514.

SABEL, C.; SIMON, W. 2004. Desestabilization rights: how public law litigation succeeds. Harvard Law Review, v. 117, n. 4, p. 1016.

SEMINARIO EN LATINOAMÉRICA DE TEORÍA CONSTITUCIONAL Y POLÍTICA (SELA). 2001. Estado de derecho y democracía: Un debate acerca del rule of law (SELA 2000). Buenos Aires: Editores del Puerto.

SIKKINK, Kathryn; RISSE, Thomas. 1999. The Socialization of International Human Rights Norms into Domestic Practices: Introduction. In: ; ROPP, Stephen C. The Power of Human Rights. International Norms and Domestic Change. Cambridge: Cambridge University Press, p. 1-39.

SIKKINK, K. 2003. La dimensión Transnacional de los Movimientos Sociales. In: JELIN, E. (Org.). Más allá de la Nación: Las Escalas Múltiples de los Movimientos Sociales. Buenos Aires: Libros del Zorzal, p. 301-335.

TAYLOR, C. 1992. El Multicuralismo y la Política del Reconocimiento. México DF: Fondo de Cultura Económica.

TISCORNIA, S. 2008. Activismo de los Derechos Humanos y Burocracias Estatales. El caso Walter Bulacio. Buenos Aires: CELS, Editores del Puerto.

YOUNG, I. M. 1996. Vida Política y Diferencia de Grupo. In: Perspectivas Feministas en Teoría Política. Madrid: Editorial Paidos, p. 120.

\section{Jurisprudência}

ARGENTINA. 2005. Corte Suprema Argentina. Simón, Julio Héctor y otros. 14 Jun. 2006. Corte Suprema Argentina. Lavado, Diego Jorge y otros v. Provincia de Mendoza sobre acción declarativa de certeza. 6 Set.

CHILE. 2007. Corte Suprema do Chile. Segunda Sala. Hechos acaecidos en el regimiento Cerro Chena. 13 Mar. 
COLÔMBIA. 2004. Corte Constitucional. Sentença T-025. 22 Jan. [Juiz relator: Manuel José Cepeda Espinosa].

2008. Corte Constitucional. Auto 092. 14 Abr. [Juiz relator: Manuel José Cepeda Espinosa]

2009. Corte Suprema de Justiça. Sala de Cassação Penal. Conceito desfavorável à extradição de Edgar Medina Flores, 19 Jul.

COMISSÃO INTERAMERICANA DE DIREITOS HUMANOS (CIDH). 2001a. Maria Da Penha Maia Fernandes v. Brasil. Caso 12.051, Relatório 54/01, 16 Abr.

2001b. María Merciadri de Moroni v. Argentina. Caso 11.307, Relatório 103/01, 11 Out.

. 2002. Simone André Diniz v. Brasil. Relatório 37/02, 9 Out.

. 2006. Jorge Castañeda Gutman v. México. Relatório de Admissibilidade e Mérito 113/06, par. 173-174, 26 Out.

8 Mar.

2007a. Nicaragua v. Costa Rica. Caso Interestatal 01/06, Relatório 11/2007,

. 2007b Renato Ticona Estrada y otros v. República de Bolivia. Demanda perante a Corte Interamericana de Direitos Humanos. Caso 12.527, 8 Ago.

. 2007c. Campo Algodonero: Claudia Ivette González, Esmeralda Herrera

Monreal y Laura Berenice Ramos Monárrez v. México. Demanda perante a Corte Interamericana de Direitos Humanos. Casos 12.496, 12.497 e 12.498, 4 Set.

_. 2007d. Luis de Jesús Maldonado Manzanilla v. México. Relatório 87/2007, 17 Out.

. 2008a. Dudley Stokes v. Jamaica. Caso 12.468, Relatório de Mérito 23/08, 14 Mar.

. 2008b. Rosendo Radilla Pacheco v. México. Demanda perante a Corte Interamericana de Direitos Humanos. Caso 12.511, 15 Mar.

. 2008c. Jorge Castañeda Gutman v. México. Demanda perante a Corte Interamericana de Direitos Humanos. Casos 12.535, 6 Ago.

2009a. Sebastião Camargo Filho v. Brasil. Caso 12.310, Relatório de

Admissibilidade e Mérito 25/09, 19 Mar..

. 2009b. Wallace de Almeida v. Brasil. Caso 12.440, Relatório 26/09, 20 Mar.

. 2009c. Julia Gomez Lund y otros (Guerrilla do Araguaia) v. Brasil. Demanda perante a Corte Interamericana de Direitos Humanos. Caso 11.552, 26 Mar.

. 2009d. Asociación Nacional de Ex Servidores del Instituto Peruano de

Seguridad Social y otras v. Perú. Caso 12.670, Relatório de Admissibilidade e Mérito 38/09, 27 Mar. 
CORTE INTERAMERICANA DE DIREITOS HUMANOS (CORTE IDH). 1986. La Expresión Leyes en el Artículo 30 de la Convención Americana sobre Derechos Humanos. Opinião Consultiva OC-6/86, 9 Mai.

1987a. El Hábeas Corpus Bajo Suspensión de Garantías (arts. 27.2, 25.1 y 7.6 Convención Americana sobre Derechos Humanos). Opinião Consultiva OC-8/87, 30 Jan.

. 1987b. Garantías Judiciales en Estados de Emergencia (arts. 27.2, 25 y 8 Convención Americana sobre Derechos Humanos). Opinião Consultiva OC-9/87, 6 Out.

1990. Excepciones al agotamiento de los recursos internos (arts. 46.1, 46.2 a y 46.2.b CA). Opinião Consultiva OC-11/90, 10 Ago.

2001. La Comunidad Mayagna (Sumo) Awas Tingni v. Nicaragua. Série C No. 79, 31 Ago.

. 2004a. Masacre Plan de Sánchez v. Guatemala. Mérito. Série C No. 105, 29 Abr.

. 2004b. Carpio Nicolle y otros v. Guatemala. Mérito, Reparaçôes e Custas.

Série C No. 117, 22 Nov.

.2005a. Comunidad Moiwana v. Surinam. Exceções Preliminares, Mérito,

Reparaçôes e Custas. Série C No. 124, 15 Jun.

2005b. Comunidad Indígena Yakye Axa v. Paraguay. Mérito, Reparaçōes e

Custas. Série C No. 125, 17 de Jun.

.2005c. Yatama v. Nicaragua. 23 Jun.

. 2005d. Nińas Yean y Bosico v. República Dominicana. 8 Set.

. 2006a. Caso Comunidad Indígena Sawhoyamaxa v. Paraguay. Mérito,

Reparaçóes e Custas. Série C No. 146, 29 Mar.

. 2006b. Almonacid Arellano y otros v. Chile. Série C No. 154, 26 Set. 2007. Pueblo de Saramaka v. Suriname. Série C No. 172, 28 Nov.

. 2008. Jorge Castañeda Gutman v. México. Série C No. 184, par. 172, 6 Ago.

2009a. Asunto del Pueblo Indígena Kankuamo. Medidas Provisórias a respeito da República da Colômbia, 3 Abr.

2009b. Las Masacres de Mapiripan v. Colombia. Resolução de Supervisão de Cumprimento de Sentença, 7 Jul. Disponível em: <http://www.corteidh.or.cr/docs/ supervisiones/ituango_07_07_09.pdf> Último acesso em: Nov. 2009.

2009c. Asunto Comunidades del Jiguamiandó y del Curbaradó. Medidas

Provisórias a respeito da República da Colômbia, 17 Nov.

PERU. 2005. Tribunal Constitucional. Sentença. Barrios Altos v. Perú [Caso "Santiago Martín Rivas"]. 29 Nov. 


\section{NOTAS}

1. A Corte IDH invalidou a autoanistia chilena em (CORTE IDH, Almonacid Arellano e outros v. Chile, 2006b). Sem citar esse precedente, pode-se encontrar argumentos de direito internacional humanitário e de direito internacional dos direitos humanos nos fundamentos das decisões da Corte Suprema chilena que invalidaram constitucionalmente essa norma (CHILE, Hechos acaecidos en el regimiento Cerro Chena, 2007).

2. Nessas opiniões a Corte IDH desenvolve uma doutrina básica sobre a relação entre direitos humanos, garantias processuais, estado de direito e sistemas democráticos, com órgãos de representação da vontade popular.

3. Ver a doutrina exposta pela CIDH em seus informes de inadmissibilidade mais recentes, inclusive para inibir-se de revisar condenações penais alegadamente injustas, diante da impossibilidade de substituir os tribunais nacionais na valoração da prova (CIDH, Luis de Jesús Maldonado Manzanilla v. México, 2007d). É certo que o limite entre a revisão do conteúdo das sentenças, ou da avaliação da prova do julgamento, e o exame da ofensa a certas garantias processuais fixadas pela Convenção é às vezes de difícil definição e requer o aprimoramento de padrões técnicos.

4. Ver o debate sobre obrigações positivas do Estado em matéria eleitoral e a margem de deferência para definir sistemas eleitorais e de partidos políticos (CIDH, Jorge Castañeda Gutman v. México, 2006, 2008c; CORTE IDH, 2008).

5. Ver como exemplo relatório sobre a situação de direitos humanos de um país em que coleta a agenda de exclusão social e a perspectiva de incidência em políticas públicas: (CIDH, 2003, 2007d).

6. Sobre o valor dos relatórios temáticos, como ferramentas de incidência da CIDH no contexto de democracias deficientes na região, ver a análise precisa de (FARER, 1998). Como exemplo desses relatórios temáticos, ver (CIDH, 2006a). Como modelos de relatórios temáticos aplicados a um contexto nacional, ver (CIDH, 2006b, 2009a, 2009b).

7. Ver (CIDH, Nicarágua v. Costa Rica, 2007). Em junho de 2009, a Procuradoria do Equador apresentou uma petição contra Colômbia perante a Secretaria Executiva da CIDH alegando violações à Convenção Americana, pela morte do Sr. Franklin Aisalia, como resultado de operação militar colombiana de março de 2008 contra um acampamento das FARC localizado em território equatoriano de Angostura.

8. Nesse sentido sustentou a Corte no caso Meninas Yean e Bosico v. República Dominicana
(CORTE IDH, 2005d): "A Corte considera que o princípio de direito imperativo de proteção igualitária e efetiva da lei e não discriminação determina que os Estados, ao regular os mecanismos de outorga da nacionalidade, devem se abster de produzir regulamentos discriminatórios ou que tenham efeitos discriminatórios em relação aos diferentes grupos de uma população no exercício de seus direitos. Ademais, os Estados devem combater as práticas discriminatórias em todos seus níveis, especialmente nos órgãos públicos, e por fim devem adotar as medidas afirmativas necessárias para assegurar uma efetiva igualdade perante a lei para todas as pessoas".

9. Pode-se consultar as medidas provisórias da Corte IDH, no caso do Povo indígena Kankuamo (CORTE IDH, 2009a), e das comunidades afrocolombianas de Jiguamiandó e Curbaradó (CORTE IDH, 2009C), entre muitas outras. Ver ademais para ilustrar o tipo de situações coletivas mencionadas no marco do conflito armado colombiano (CIDH, 2008d).

10. Sobre as obrigações positivas dos Estados de garantir o exercício de certos direitos civis, políticos e sociais pelos membros das comunidades indígenas, ver os casos Massacre de Plan Sanchez v. Guatemala (CORTE IDH, 2004a); caso Comunidade Moiwana v. Suriname (CORTE IDH, 2005a); e Comunidade Indígena Yakye Axa v. Paraguai (CORTE IDH, 2005b). Recentemente esse princípio levou a Corte a reinterpretar as obrigações do Estado em matéria de direito à vida para incorporar um dever de garantir certos mínimos vitais de saúde, água e educação, vinculados com o direito à vida digna de uma comunidade indígena expulsa de seu território coletivo, no caso de Sawhoyamaxa vs Paraguai (CORTE IDH, 2006a) e subsequentes decisões de supervisão de sentença.

11. Ver o caso Simone André Diniz contra Brasil (CIDH, 2002) declarado admissível pela CIDH, em que se alega o descumprimento do dever estatal de proteção frente a condutas discriminatórias de particulares, baseadas na cor ou raça.

12. Sobre a obrigação de adotar políticas e medidas positivas para prevenir, punir e erradicar a violência contra as mulheres, ver (CIDH, Maria da Penha Maia Fernandes v. Brasil, 2001a.).

13. Sobre cotas no sistema eleitoral argentino, (CIDH, 2001b).

14. Para uma análise dessas noções de igualdade na filosofia jurídica e no direito constitucional vejam, a título de exemplo: (YOUNG, 1996, FERRAJOLI, 1999, GARCIA AÑON, 1997, FISS, 1999, GARGARELLA, 2008, SABA, 2004).

15. Sobre os direitos coletivos relativos à preservação da sobrevivência de uma cultura e 
neutralidade do Estado liberal, veja o clássico ensaio de Charles Taylor (1992) e também Anaya (2005).

16. Nessa sentença a Corte começa a definir o alcance do direito à participação política consagrado no artigo 23 da Convenção Americana e considera que compreende além da participação em processos eleitorais formais também a participação em outros mecanismos de discussão e fiscalização de políticas públicas. Também se procura avançar na sentença com maiores definições sobre o alcance da obrigação estatal de garantir esse direito de participação a respeito de grupos sociais excluídos ou que se encontram em situação de desvantagem no exercício desse direito. Para tanto, o tribunal vincula o direito à igualdade, compreendido como igualdade não apenas formal mas também material, com o direito de associação e de participação política. Ver nesse sentido o voto concorrente do juiz Diego García Sayan. Para entender melhor o sentido que a própria Corte IDH dá à sua decisão no caso Yatama, sugere-se ler também como o diferencia de um caso posterior sobre exclusão de candidaturas independentes, considerando especialmente em Yatama a existência de um grupo subordinado com características de identidade cultural diferenciadas (CORTE IDH, Jorge Castañeda Gutman v. México, 2008).

17. Inspirando-se no caso Airey, a Corte sustentou que: "as circunstâncias de um procedimento específico, seu significado, sua natureza e seu contexto num sistema jurídico particular, são fatores que fundamentam a determinação sobre se a representação legal é ou não necessária para o devido processo", pár. 28. Também se referiu expressamente a Corte sobre a obrigação estatal de garantir serviços jurídicos gratuitos às pessoas sem recursos quando seja indispensável para garantir o acesso efetivo e igualitário à justiça na OC 18/03 Condição Jurídica e Direitos dos Migrantes Indocumentados. Nesse documento sustentou a Corte: "Viola-se o direito às garantias e à proteção judicial por vários motivos: pelo risco de a pessoa, quando aciona as instâncias administrativas ou judiciais, de ser deportada, expulsa ou privada de sua liberdade, e pela negativa da prestação de um serviço público gratuito de defesa jurídica a seu favor, o que impede que se façam valer seus direitos em juízo. A esse respeito, o Estado deve garantir que o acesso à justiça seja não apenas formal, mas sim real" (CORTE IDH, Opinião Consultiva OC-11/90, 1990).

18. Também os indicadores sobre acesso à justiça e direitos sociais desenvolvidos no documento da CIDH (2008a).

19. John Elster utilizou essa metáfora para se referir ao ato constituinte em seu livro "Ulises y las sirenas: estudios sobre racionalidad e irracionalidad" (1979).

20. Para alguns autores, como Andrew Moravcsik, as democracias recentemente estabelecidas e potencialmente instáveis são as que encontram mais justificativas para a subscrição de tratados de direitos humanos e inserção em sistemas internacionais como mecanismos para a consolidação da democracia. A renúncia a certos níveis de autodeterminação que implica a assinatura desses tratados e a aceitação de jurisdições internacionais tem um custo pela limitação da discricionariedade governamental e do sistema político local, que joga num balanço com as vantagens da redução da incerteza política (MORAVCSIK, 2000). No mesmo sentido, ver Kahn, Paul W. (2002).

21. Por exemplo a jurisprudência da Corte Suprema argentina nos casos "Giroldi"; "Poblete"; "Arancibia Clavel", entre outros (ABRAMOVICH; BOVINO; COURTIS, 2006).

22. Martín Bohmer, contestando críticas formuladas à ausência de validação democrática do direito internacional, ressalta que o momento de validação não pode ser limitado ao da celebração do tratados ou aprovação de normas internacionais, mas que compreende também o processo de interpretação e aplicação pelos órgãos locais judiciais e políticos. Assim, as normas internacionais não são um produto acabado e unívoco, mas que estão abertos a diferentes leituras que se dão no plano nacional e autorizam esse processo e leitura ao incorporar níveis de deliberação, assim como consideração do contexto social e político de cada comunidade (BÖHMER, 2007).

23. Nesse sentido, ao responder a pergunta sobre por que os Estados deveriam respeitar o direito internacional, Harold Koh propõe considerar que a aceitação das obrigações jurídicas internacionais é fruto de um "processo jurídico transnacional" que consiste num conjunto de subprocessos complexos e de variadas dimensões que incluem a articulação, interpretação e incorporação do direito internacional no âmbito local, por meio de mecanismos políticos, sociais e jurídicos $(\mathrm{KOH}$, 1996, 1997, 2004).

24. Por exemplo quando recebe informação sobre situações específicas para elaborar seus relatórios, seja por meio de audiências em sua sede, ou nas visitas ao país.

25. Essa situação se observa por exemplo em alguns casos sobre superpopulação e violência nos presídios estaduais no Brasil e Argentina, nos quais a intervenção do SIDH motivou distintas formas de intervenção da autoridade federal nos sistemas penitenciários locais. Também por exemplo num acordo recente de solução amistosa celebrada com o governo federal do México que motivou a adoção pelos estados locais de um protocolo sobre abortos não puníveis.

26. Por exemplo na Colômbia a CIDH utilizou as decisões da Corte Constitucional sobre deslocados internos como marco para acompanhar situações de direitos humanos (COLOMBIA, T-025, 2004, CIDH, 2007b, 2007e). Em sentido inverso, algumas decisões da Corte Constitucional, por exemplo 
sobre mulheres desalojadas no âmbito do conflito colombiano, determinaram obrigações de prestação ao Estado, considerando como fundamento decisões, relatórios de situação e jurisprudência do sistema interamericano de direitos humanos, entre outros parâmetros constitucionais. Inclusive uma recente decisão da Corte Constitucional convida a $\mathrm{CIDH}$ a se integrar a um sistema de monitoramento do cumprimento da sentença doméstica (COLOMBIA, Auto 92, 2008).

27. Essa situação se deu, por exemplo, nos acordos de solução amistosa sobre a anistia peruana no caso Barrios Altos, em que o governo peruano, os peticionários e a CIDH solicitaram à Corte IDH que definisse os parâmetros sobre compatibilidade das leis de anistia de graves violações aos direitos humanos com a Convenção Americana, a fim de oferecer um marco jurídico aos tribunais nacionais para que procedessem a reabertura dos casos judiciais arquivados em virtude dessas leis. Também, por exemplo, os acordos de solução amistosa sobre a tramitação de causas judiciais sobre o direito à verdade na Argentina, celebrados por peticionários e o governo, contribuíram para comprometer a atuação do sistema judicial local na sua implementação.

28. Ver por exemplo a intervenção da CIDH nos conflitos relacionados com a situação de semiescravidão de famílias indígenas guaranis em fazendas do Chaco boliviano e os empecilhos para a implementação da legislação sobre reforma agrária nas regiões do oriente boliviano (CIDH, 2008b).

29. Ver por exemplo a recente decisão da Sala de Cassação Penal da Corte Suprema Colombiana que limita a faculdade de extraditar aos Estados Unidos membros das AUC que estejam participando do processo de Justiça e Paz na Colômbia. A Corte considera que a extradição dificulta a investigação dos casos de direitos humanos e a confissão dos acusados afetando o direito à justiça e à verdade das vítimas. A Corte Suprema se baseia na jurisprudência internacional e considera especialmente a decisão de implementação da Corte IDH no caso do massacre de Mapiripan. Sobre o tema havia se pronunciado previamente com iguales argumentos a CIDH (COLOMBIA, 2009, CORTE IDH, Massacres de Mapiripan v. Colômbia, 2009b, CIDH, 2008c).

30. 0 autor revisa alguns questionamentos que podem ser formulados de uma teoria da democracia deliberativa ao valor de autoridade das decisões de órgãos internacionais de proteção, muitos dos quais admitimos nesse artigo. Propõe uma série de problemas constitucionais e de déficit democrático que os internacionalistas não costumamos nos perguntar. Isso, apesar de apresentar uma visão a meu ver um tanto quanto esquemática do processo social, político e jurídico complexo que conduziu à construção de consensos para a anulação das leis de anistia pelo Congresso e pela Justiça na Argentina. Para uma crítica de algumas objeções "comunitaristas" à aplicação do direito internacional dos direitos humanos na Argentina, V. Abramovich, "Editorial", Nueva Doctrina Penal, 2007-B. Também pode acompanhar o debate entre Carlos F. Rosenkrantz e Leonardo Filippini (ROSENKRANTZ, 2005, 2007, FILIPPINI, 2007).

31. No caso Carpio Nicolle contra Guatemala (CORTE IDH, 2004b), a Corte IDH considerou o conceito de "coisa julgada aparente ou fraudulenta" em função não apenas das circunstâncias do processo judicial em questão, mas também do contexto e da existência de um "padrão sistemático de impunidade" de certos crimes de estado. Novamente há aqui uma perspectiva que indica examinar desigualdades na aplicação da lei penal em benefício de certos setores privilegiados ou em prejuízo de outros grupos sociais subjugados. Nesse caso a desigualdade perante a lei é o fundamento da desqualificação da decisão judicial que arquiva o processo e isso permite relativizar também o princípio da coisa julgada e de ne bis in idem (KRSTICEVIC, 2007).

32. Colômbia e Peru sancionaram normas sobre implementação e coordenação intergovernamental que são um modelo a considerar.

33. Ver o caso "Lavado, Diego Jorge y otros v. Provincia de Mendoza sobre acción declarativa de certeza", da Corte Suprema Argentina (2006). Trata-se da decisão da Corte Suprema argentina que discute a implementação das medidas provisórias aplicadas pela Corte IDH no assunto das Penitenciárias de Mendoza a respeito de Argentina.

34. Por exemplo, existe um debate sobre o grau de precisão que se requer na identificação das vítimas em casos de natureza coletiva. Necessita-se em todos os casos nomear a cada pessoa afetada, ou o SIDH, que ingressou no tratamento de padrões estruturais e o reconhecimento de "direitos de grupos", deve adaptar seus procedimentos a essa nova agenda, e aceitar a identificação de grupos ou "classes" como vítimas, especialmente na etapa de reparações e nas medidas de proteção cautelar. 0 risco é uma certa esquizofrenia, ou um desenvolvimento em direções opostas, entre a jurisprudência sobre igualdade e as decisões em matéria processual. 


\begin{abstract}
The Inter-American System of Human Rights (ISHR), during the last decade, has influenced the internationalization of legal systems in various Latin American countries. This led to the gradual application of ISHR jurisprudence in constitutional courts and national supreme courts, and most recently, in the formulation of some state policies. This process resulted in major institutional changes, but there have been problems and obstacles, which have led to some setbacks. The ISHR finds itself in a period of intense debates, which seek to define thematic priorities and the logic of intervention, in the context of a new regional political environment of deficient and exclusionary democracies, different from the political landscape in which the ISHR was born and took its first steps.

This article seeks to present an overview of some strategic discussions about the role of the ISHR in the regional political sphere. This article suggests that the ISHR should in the future intensify its political role, by focusing on the structural obstacles that affect the meaningful exercise of rights by the subordinate sectors of the population. To achieve this, it should safeguard its subsidiary role in relation to the national justice systems and ensure that its principles and standards are incorporating not only the reasoning of domestic courts, but the general trend of the laws and governmental policies.
\end{abstract}

\title{
KEYWORDS
}

Inter-American System of Human Rights - Human rights violations - Internationalization of domestic legal systems

\section{RESUMEN}

El Sistema Interamericano de Derechos Humanos (SIDH) ha incidido en la última década en el proceso de internacionalización de los sistemas jurídicos en varios países de América Latina. La jurisprudencia del SIDH se comenzó a aplicar gradualmente en las decisiones de los tribunales constitucionales y las cortes supremas nacionales, y en los últimos tiempos en la formulación de algunas políticas estatales. Este proceso produjo importantes cambios institucionales, pero también enfrenta problemas y obstáculos, lo que lo ha llevado a sufrir algunos retrocesos. El SIDH se encuentra en un período de fuertes debates, que procuran definir sus prioridades temáticas y su lógica de intervención, en un nuevo escenario político regional de democracias deficitarias y excluyentes, diferente del escenario político que lo vio nacer y dar sus primeros pasos. Este artículo procura presentar un panorama general de algunas discusiones estratégicas acerca del rol del SIDH en el escenario político regional. En este artículo se sugiere que el SIDH debería en el futuro profundizar su rol político, poniendo la mira en los patrones estructurales que afectan el ejercicio efectivo de derechos por los sectores subordinados de la población. Para lograrlo deberá resguardar su función subsidiaria de los sistemas de protección nacionales, y procurar que sus principios y estándares se incorporen no sólo en la doctrina de los tribunales, sino en la orientación general de las leyes y las políticas de gobierno.

\section{PALABRAS CLAVE}

Sistema Interamericano de Derechos Humanos - Violaciones de derechos humanos Internacionalización de los sistemas jurídicos nacionales 